\title{
The Role of Built and Social Environments of Traditional Communities in the Formation of Social Capital
}

\author{
Mohammad Soltanzadeh* \\ Assistant professor, Faculty of Art and Architecture, Shahid Bahonar University, Kerman, Iran. \\ (Received 23 Apr 2020, Accepted 19 Jun 2020)
}

The concept of social capital views the relationships and interactions of individuals, characterized by quality or quantity, as an asset, trying to use this asset to tackle problems in different areas. This concept is deemed a reliable measure, particularly in the residential neighborhoods context. This study discusses social capital in the form of a model for traditional communities of Iran and, by proposing indicators for social and built environment of the communities, explores their relationship with the components of social capital in the framework of a model of social capital, defined at community level and characterized by three cognitive, behavioral and psychological components. Social environment indicators include the administrative system (control and management, self-sufficiency) and the social composition, while the built environment indicators consist of diversity and function, composition and structure, architecture and design. Given the complexity of the concept of social capital and the fact that built environment does not directly create social capital, the study demonstrates that the control and management system of traditional communities is in accordance with the component of empowerment in the social capital model. On the other hand, the self-sufficiency of communities and their social composition affect the sense of community. In other words, social interactions increase by the consistency of demographic patterns and the self-sufficiency of communities, which means their ability to meet the daily and weekly needs of residents through their various functions. Along with the enhancement of social interactions, the sense of community is promoted and the component of neighboring among inhabitants is strengthened. Briefly, the social environment can affect the behavioral components of social capital (neighboring) in addition to its positive impact on both cognitive component of social capital (empowerment and sense of community). The built environment of communities possess a variety of components and functions. The diversity of functions led to the emergence of self-sufficient communities in terms of meeting the needs of inhabitants, while the function of components was beyond mere functional roles; they therefore sometimes played a social role (e.g. the mosque and neighborhood square) and provided a suitable basis for the active presence of residents at community level. In other words, the correct prediction of social needs of residents and appropriate responsiveness in the built environment provided the inhabitants with spaces necessary for their social activities at community level. On the other hand, the architecture and design of elements, precise prediction or embedment of components (frontispiece, hoods, etc.), selection of materials and creation of spatial qualities (dimensions, proportions, differences, etc.) are factors that increase social interactions and promote the residents' sense of attachment to the community. At a higher level, the overall structure of community, composition of components, organization and location of functions such as house, passage and square are aimed to increase social interactions. Consequently, the built environment of communities specifically affect the sense of community (cognitive component), neighboring (behavioral component) and sense of attachment (psychological component) by: (1) increasing the level of social interaction, and (2) enhancing the sense of belonging to the community.

Keywords: Social capital, Built environment, Social environment, Iran, Traditional community.

\footnotetext{
${ }^{*}$ Corresponding author. E-mail: msoltan@uk.ac.ir
} 


\section{واكاوى ظرفيتهاى محيط كالبدى و اجتماعى محلات تاريخى

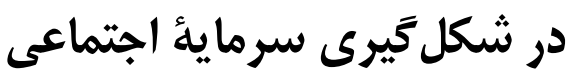

\section{محمد سلطانز اده"}

استاديار دانشكده هنر و معمارى، دانشخاه شهيد باهنر، كرمان، ايران.

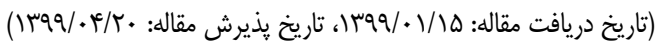

حوزههاى مختلف علوم، با طرح مفاهيمى مانند سرمائُ اجتماعى در يى بيان ملموس و تحليل يذير بديدههاى غامض

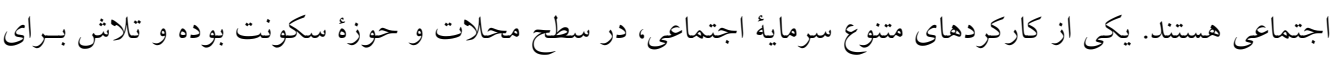
حفظ و يا افزايش آن، راهكارى براى مقابله با برخى ناهنجارىها و معضلات اجتماعى محلات، دانسته شده اسـت.

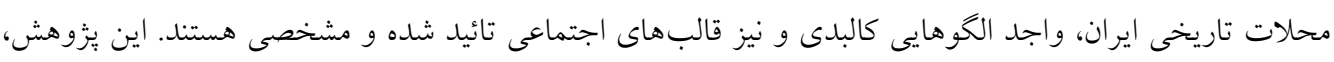

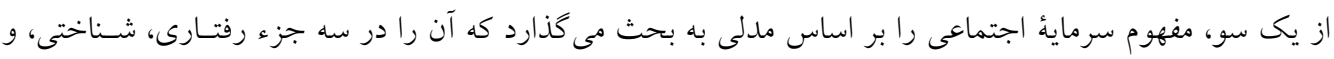

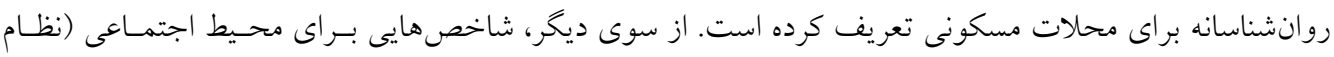

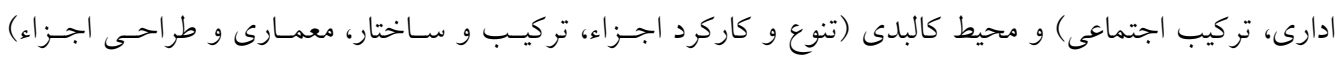

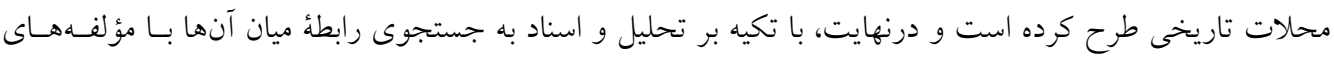

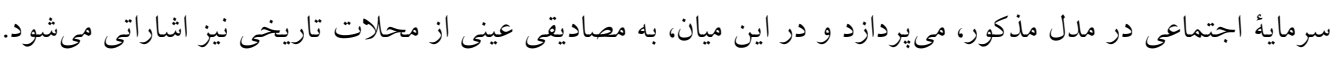

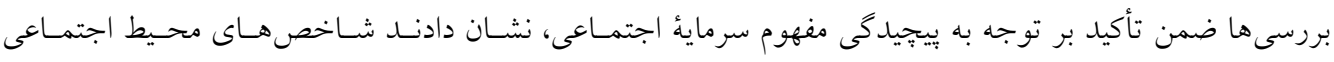

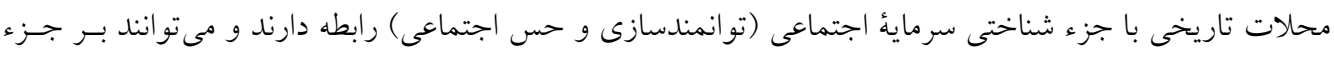
رفتارى آن نيز اثركذار باشند. شاخصهاى محيط كالبدى بر جزء رفتارى (همسـايه دارى)، روانشناسـانه (تعلـق بــهـ

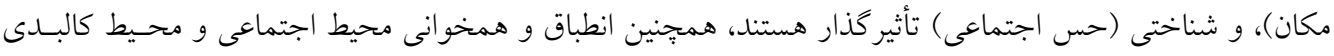
محله، عاملى ضرورى و مؤثر براى افز ايش سرمائُ اجتماعى ساكنان بوده است.

وازَّان كليدى سرمائُ اجتماعى، محلات تاريخى، محيط كالبدى، محيط اجتماعى، ايران. msoltan@uk.ac.ir : نويسنده مسئول مكاتبات:" 


\begin{abstract}
كميـت روابـط در سـطوح مختلـف و در شـكلى نظـاممنـــ

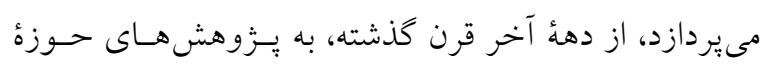

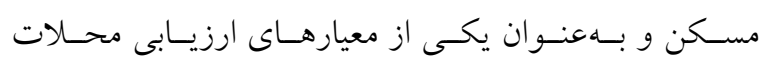

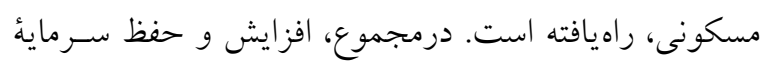

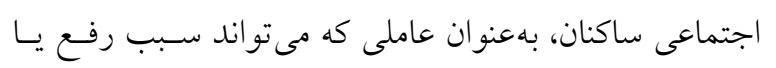

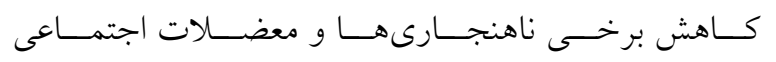

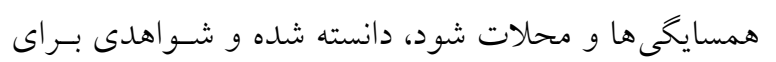

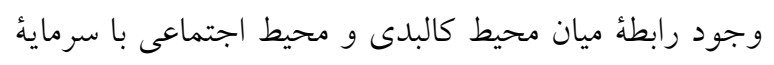
اجتماعى ساكنان، ارائهشده است.

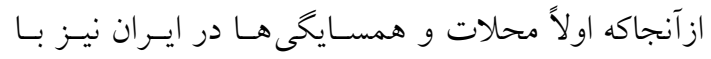

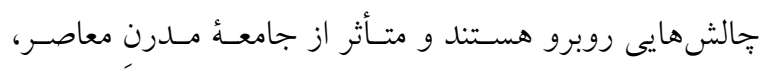

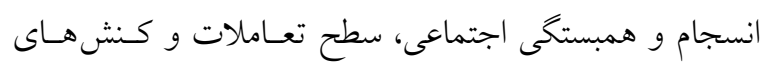

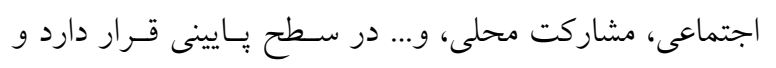

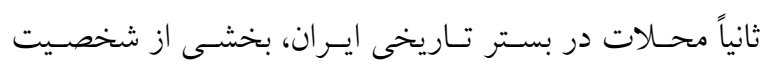

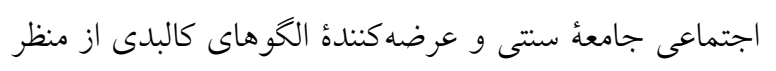

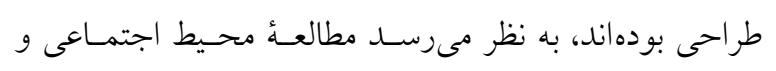

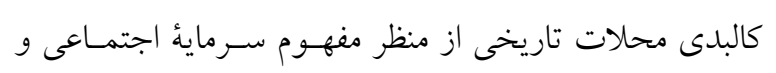
استخراج مؤلفهها يا شاخص هاى اجتمـاعى و كالبـدى مـؤثر،

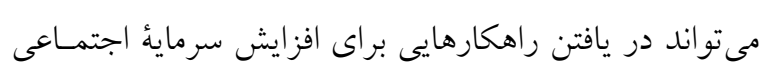
در محلات معاصر، مفيد باشد.
\end{abstract}

مقدمه

روى يُزوهش قرار مى گيرند: جه وجوهى از محيط اجتمـاعى

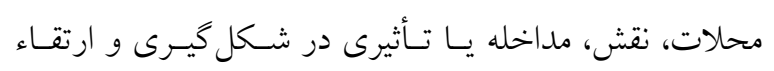

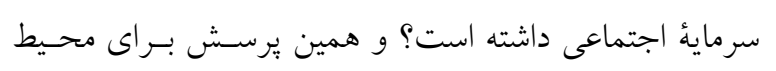

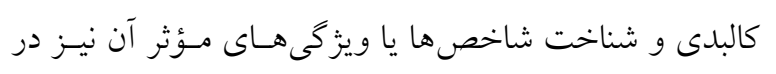

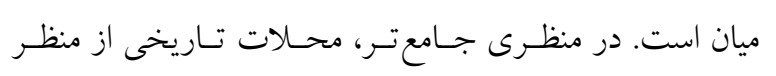

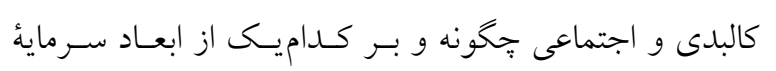
اجتماعى تأثير كذار بودهاند؟ البن بر اساس ماهيت و اهــداف يـزوهش كـه در يـى ايجـاد

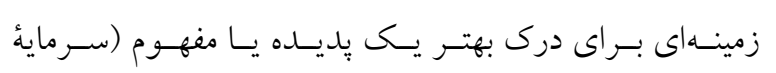

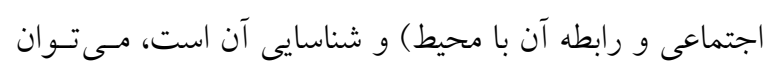

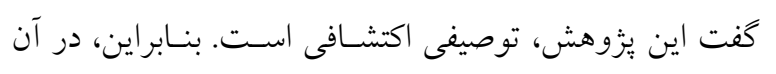

مسكن و سكونت انسـان مـــرن در شهرها بـا برسـشهـا و

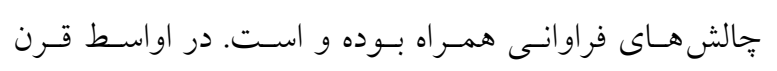

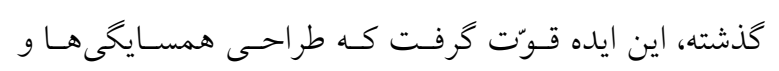

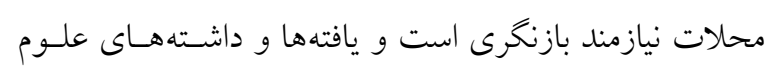

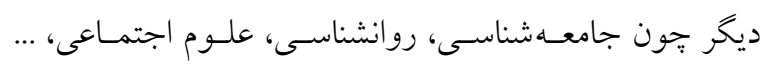

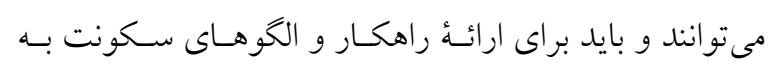

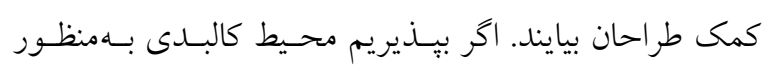

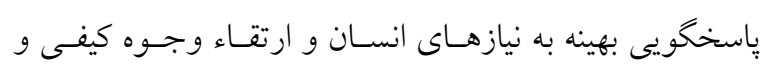

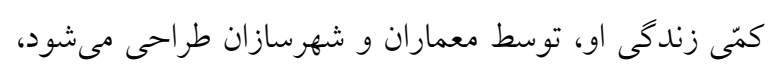

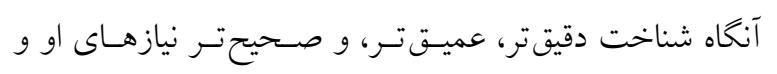

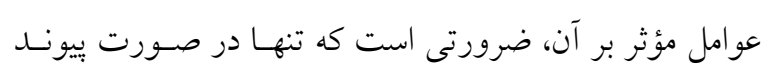
با علوم ديخر محقق خواهد شد.

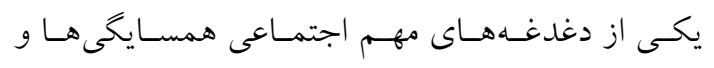

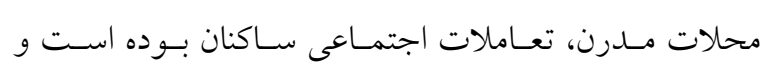

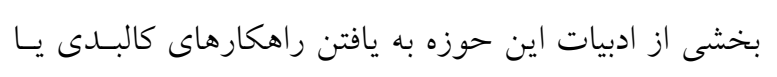

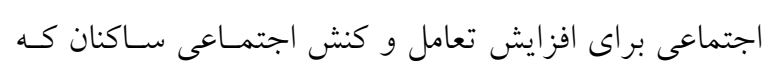

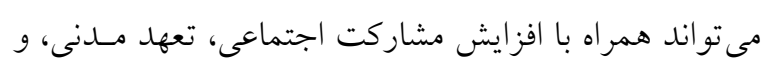

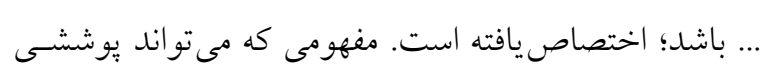

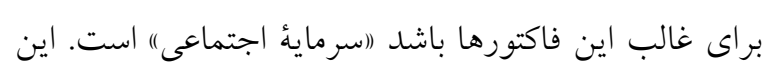

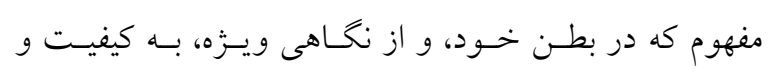

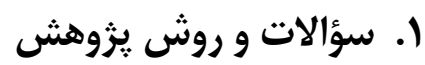

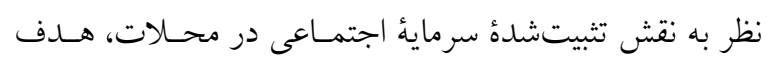

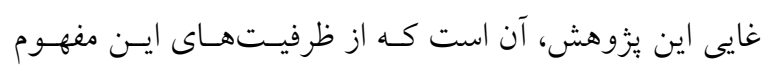

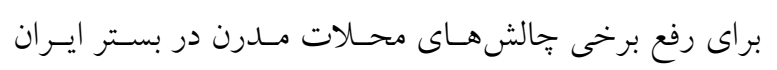

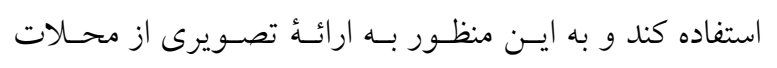

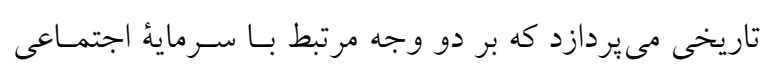

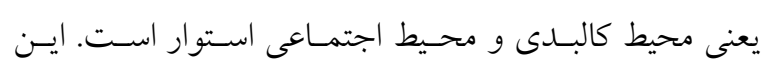

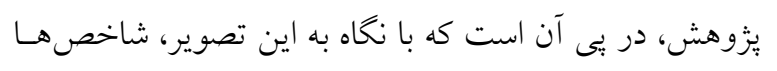

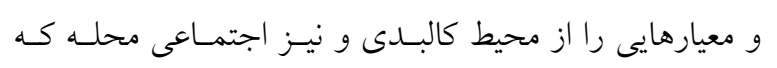
مى تواند در حفظ، شكل گيرى يا ارتقاء سرمائُ اجتماعى مؤثر

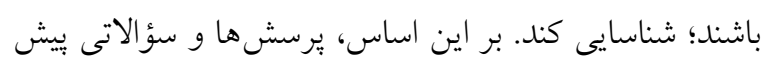


واكاوى ظرفيتهاى محيط كالبدى و اجتماعى محلات تاريخى در شكل گيرى سرمائُ اجتماعى

بررسى نقش محيط كالبدى و اجتماعى محهلات تـاريخى در شكل كيرى، حفظ و ارتقاء سرمائُ اجتماعى مى بردازد.

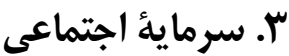

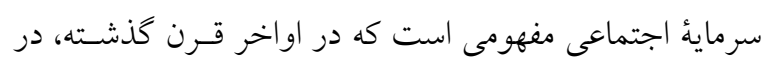
حوزهُ جامعهشناسى و علوم سياسى رشد كرده است اما طرفـه

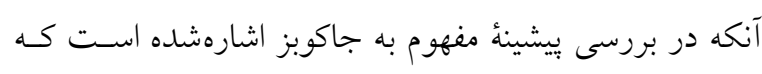

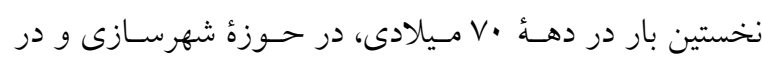
واكنش بـه معضـلات اجتمـاعى محسلات مسـكونى، عبـارت

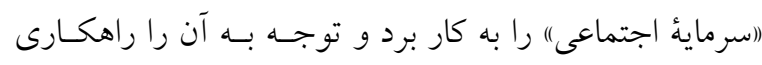

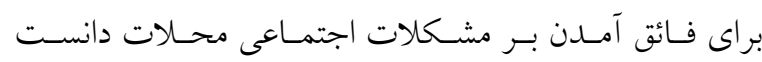

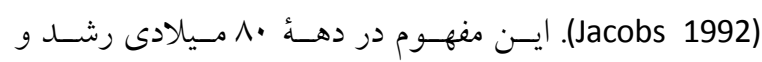
توسعهيافت و بهسرعت در ادبيات آكادميك موردتوجـه قـرار كرفت (Field 2006). از ديد كلمن، كه نقش مهمى در بسط و تئوريزه كردن اين مفهوم داشت، سرماية اجتماعى شيئى واحد

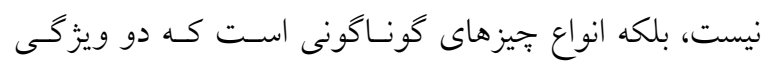

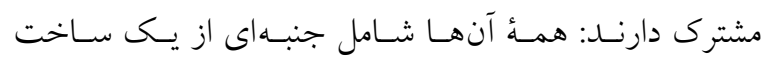
اجتمـاعى هسـتند، و كـشنشهـاى افـراد را تسـهيل مسىكنــد

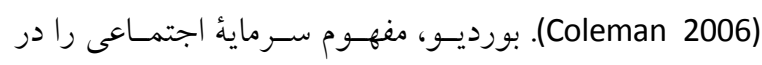
قالب بنيانهاى فكرى خود و بهعنوان يكسى از انسواع سـرمايه، طرح كرد و معتقد بود سرمائ اجتماعى حاصل انباشت منـابع بالقوه و يا بالفعلى است كه مربـوط بـهـ مالكيـت يـك شـبكة

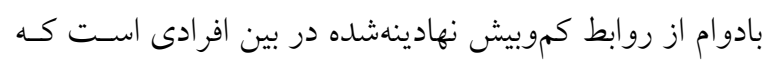
با عضويت در يك گروه ايجاد مىشـود (Bourdieu 1985). از باز

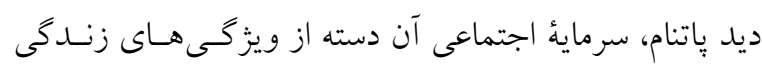

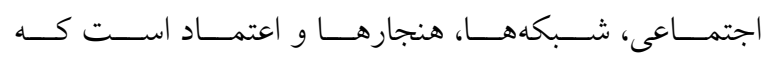

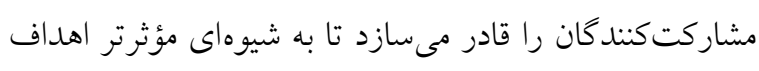
مشـترك خــود را تعقيـب كنــــ (Putnam 1996). ســرمائي

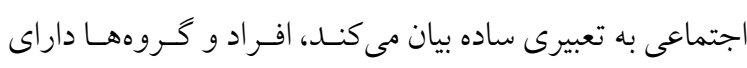

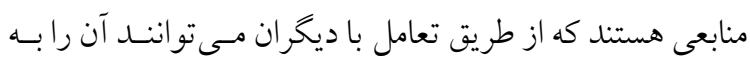
دارايى و سرمايه تبديل كنند و در جهت نيل به اهداف فردى يـا اجتماعى، توسعه و بيشرفت، غلبه بر تجالشها، وغيـره بـهــار كيرند. بر اساس مفهوم سرمائ اجتماعى، تعاملى كه كيفيـت و و

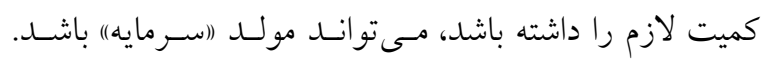

فرضيهاى طرح نشده است و براى رسيدن به هــدف، از روش اسنادى استفاده مىشود. اين بــزوهش، بــراى افـزايش اعتبـار

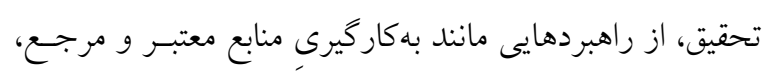
و نيز ايجاد تنوع در منابع، استفاده مى كند.

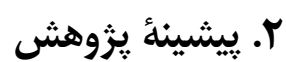

تحقيقاتى را كه به بررسى مفهوم سـرمائه اجتمـاعى در سـطح

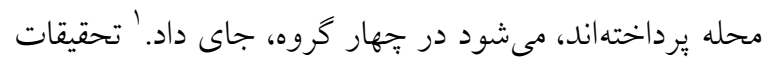
كروه نخست به بررسى عواملى كه سبب شكل كيرى و حفـظ

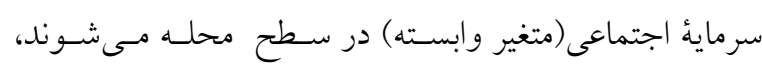
مىيردازند؛ و تحقيقات گروه دوم به بررسى نتايج يـا مزايـاى

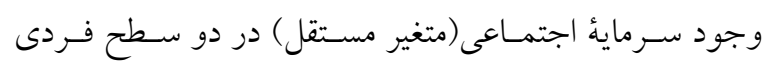

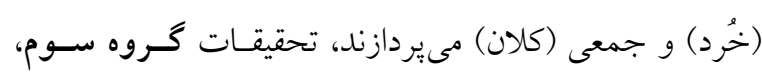

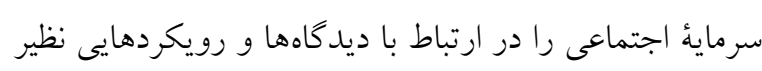

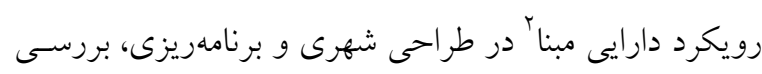

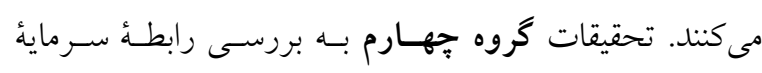
اجتماعى با محيط كالبدى و معمارى محسلات مسىيردازنـد و

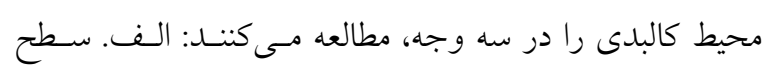

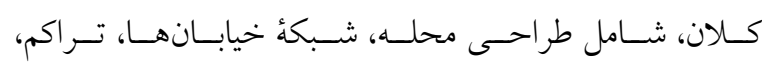

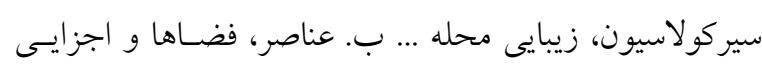
نظير مسيرهاى بيادهروى، فضاى ملاقات، فضاى سـبز و ... ج.

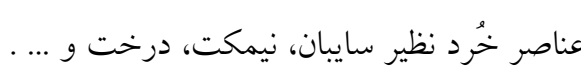
تحقيقات متعددى در ادبيات موضـوع، در غـرب و ايسران، در

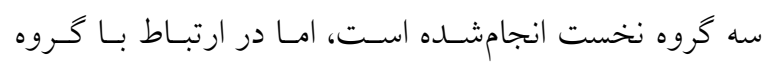
جهارم، در غرب و بهويزه در بستر ايسران، تحقيقـات محسدود هستند. در توجه به محـالات سـتىى از منظـر مفهـوم سـرمائه

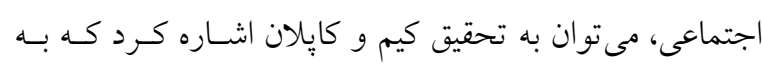

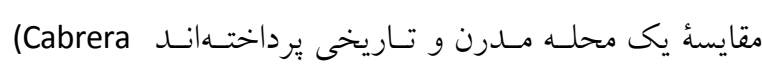

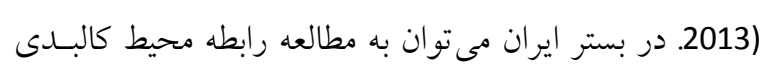

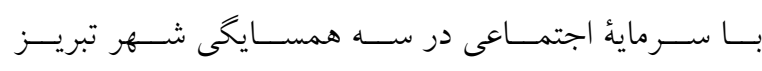

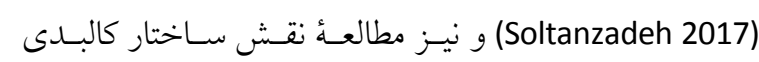

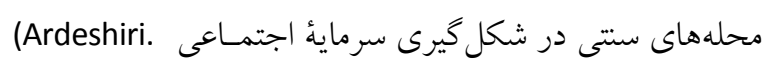
اشاره كرد. يـزروهش حاضـر، بـا Hajipoor \& Hakimi 2013) ارائهُ مللى مشخص از سرماية اجتماعى، در قالبى نظاممند بـهـ 
مشتركى كه ممكن است مـردم بـر اسـاس فاكتورهـايى نظيـر

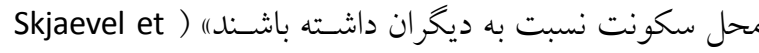
.(al. 1996, 416 كار ايیى جمعى / توانمندسازى: اعتماد به مؤثر بـودن كنشها و اقدامات اجتمـاعى سـازمانيافتسه بـوده \& Perkins ) و و بهطور كسترده در توسعه محلهاى، روانشناسى اجتمـاعى و ديخـر حسوزههـا مطالعه شده و بهكار رفته است. مطابق انتظـار، برداشـتهــاى

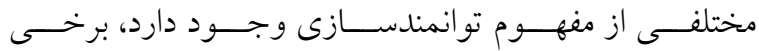
(Mihaylov \& Perkins 2013) توانمندسازى را بهعنوان فرآيندى تعريف مى كنند كه مردم در

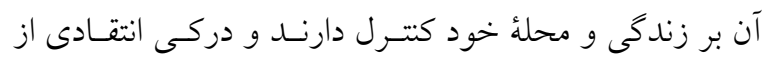
محسيط بيرامـون خــود كسـب مسى كنتـد. مسى تــوان كفــت توانمندسازى بدين معنى است كه افراد در تصميم گيـرىهـاى مختلف مرتبط با محلهُ خـود، مشـاركت مسى كنتـد زيــرا ايـن

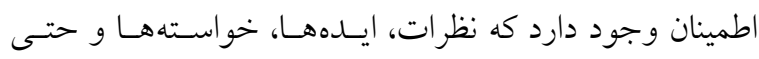
توانايىها، دارايىها و دانش آنها مفيد و مؤثر است و بدانهـا توجه مىشود.

همسايلهارىى: (اكمى دوطرفـهُ غيررسـمى و اشـتراى

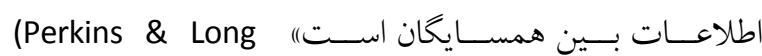

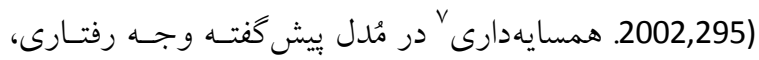
مفهوم سـرمائه اجتمـاعى محسـوب مسىشـود و مـراد از آن، كمكىهاى عمدتاً ابزارى است كه بين همسايڤان رخ مىدهــــ

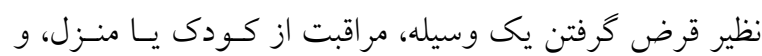

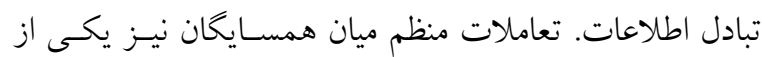
اشـكال همســايهدارى اســت و درهرحسـال، همـــة اشـكال همسايهدارى سـبب افـزايش تعـاملات و مباحثـات، افـزايش مشاركت و درنهايت، حل مشكلات محله مىشـوند Unger)

\& Wandersman, 1985)

مشاركت شهروندى: جزء رسمى و درعين حال رفتارى سرمائ اجتماعى است و اشاره به مشاركت ساكنان در كروههاى مردمى در سطح بلوى يا همسايخى نظير گروههاى دينى يا مدنى، انجمنهاى وابسته به مدرسه و ... دارد. از ديد يركينز و لانگ، اين انجمنها مىتوانند ياسخگُى دامنه
درمجموع، حمايت از سرمائُ اجتمـاعى و حفظظ و ارتقـاء آن در برنامهريزى، سياست كذارى، و يا توصسيههـايسى كـه بـراى توسعه يا بهبود محلات ارائه مىشود، جايگاهى مهم و مؤكـد يافتـه اسـت ) Forrest \& Kearns 2001; Scottish Executive (2002; Wissink \& Hazelzet 2012

\section{ع. تبيين ابعاد سرمايةُ اجتماعى}

به دلايل مختلف ازجمله، دامنهُ كاربرد كسـترده، انتظـارات يـا

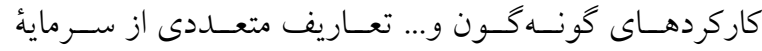
اجتماعى در حوزههاى مختلـف ارائسهشـده اسـت و محققـان مدلهاى متنوعى از آن را بر اساس اهداف، بستر، سطح و نيـز

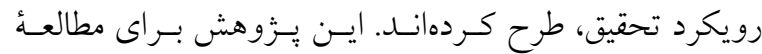

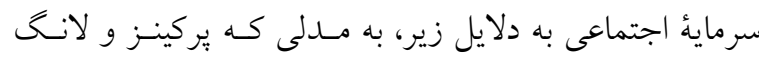
ارائه كردمانــ (Perkins \& Long, 2002)، رجـوع مسى كنـد: 1. ارائهُ مدلى منحصراً براى همسايخى و محله. r. توجه متـوازن به هر دو شـكل سـاختارى و شـناختى سـرمايةُ اجتمـاعى لّ

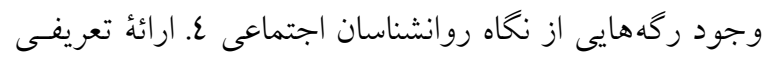
نسبتاً شفاف از اجزاء مدل. 0. توجه به بستر يزوهش. در ايسن رهن

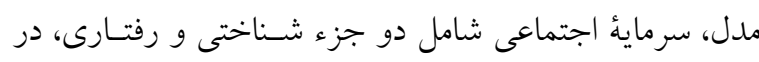
كنار وجه روانشناسانه است (تصوير (). جــزء شـناختى خــود

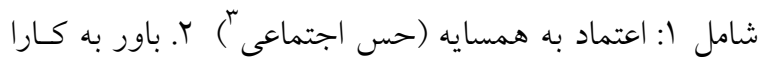

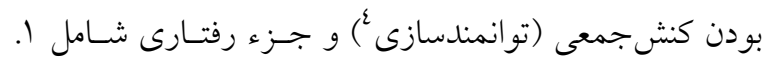

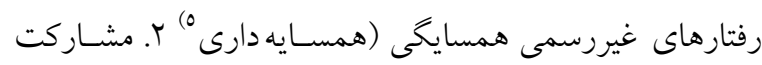

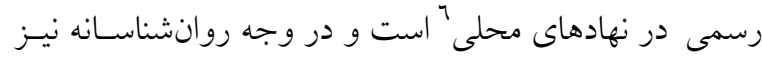
شاخص هايى جــون تعلـق بـه مكـان، رضـايت از محلـه و ... طرحشدهاند كه به شرحى موجز از آنها اشاره مىشود: حس اجتماعى: اين مفهوم كه در شهرسازى جديــ از

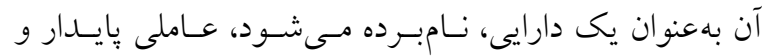

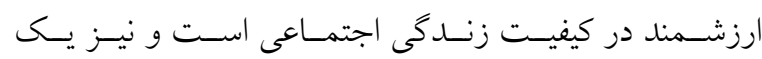

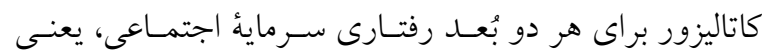
مشاركت سـازمانيافتسه و همسـايهدارى محسـوب مسى شـود (Perkins \& Long 2002). حسـ اجتمــاعى (ادر درجـــ اول

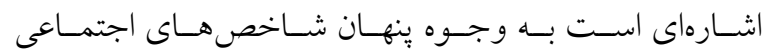

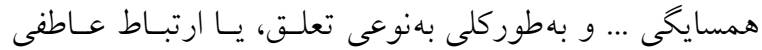


واكاوى ظرفيتهاى محيط كالبدى و اجتماعى محلات تاريخى در شكل كيرى سرمائ اجتماعى

محله كر ايى ارزش يبدا مى كند و خود، سبب ترغيب افـراد بـهـ

مشاركت كروهى بيشتر مى شود (Perkins \& Long, 2002).

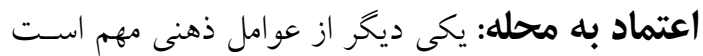
كه در صورت فقدان آن (بهويزه در محلات قـديمى) سـاكنان

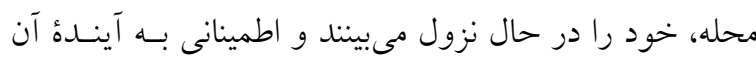

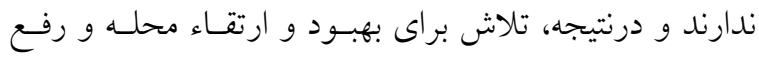

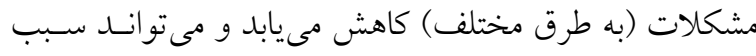
مهاجرت از محله شود (Perkins \& Long 2002).

\section{ه. تبيين ساختار محلات تاريخى در نسبت با ابعاد}

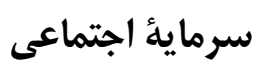
محله، در شهرهاى تاريخى ايران" همجيون سلول اصلى شهـر

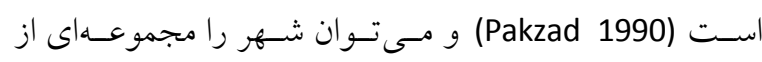
محلات متجانس دانست (Tavasolli 2012). هر محله، عـلاوه

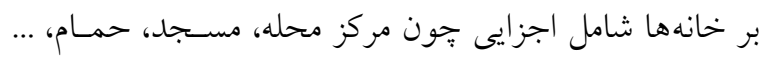

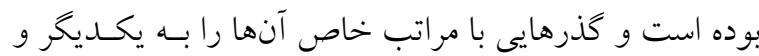

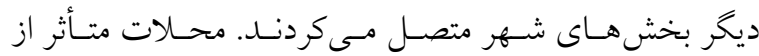
بنيانهاى اجتماعى، در كنار حكومت، امت و اصناف (بـازار)،

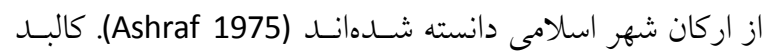

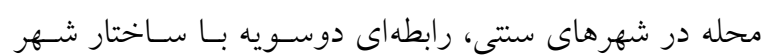

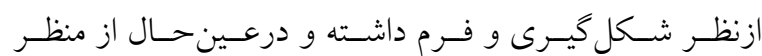

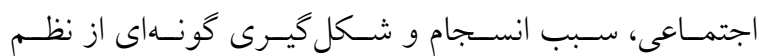

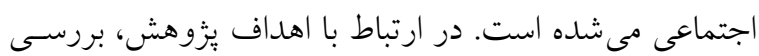

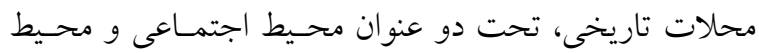

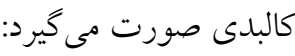

\section{0-1) - ا. محيط اجتماعى}

كنكاش در محيط اجتمـاعى محهلات در دو عنـوان شـامل 1.

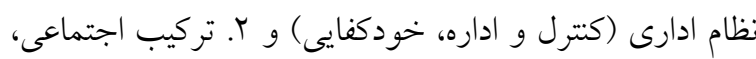

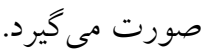

\section{الف. نظام ادارى}

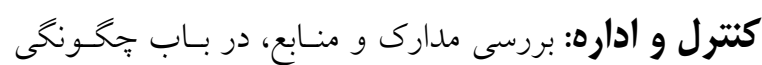
كترل و ادارة محلات تاريخى و شيوه ارتباط آنها با نهادهاى

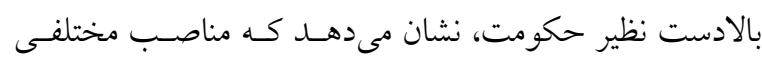

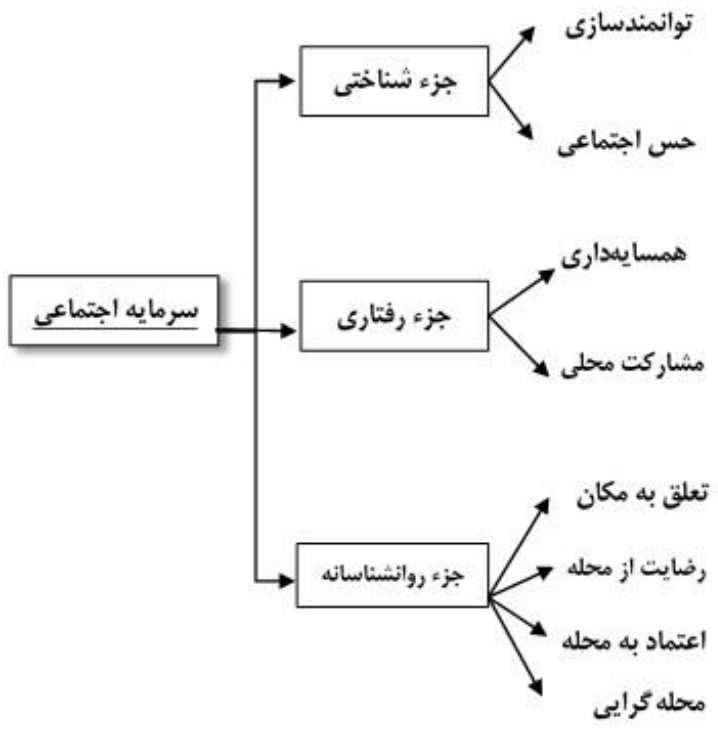

تصوير (: مدل سرمائُ اجتماعى و اجزاء آن (Perkins \& Long 2002) Fig. 1: Social capital model and its components (Perkins \& Long 2002)

متنوعى از نيازهاى محلى نظير طراحى محله، مسائل ترافيكى، نظافت منطقه، فضاهاى جرمخيـز، برنامـهــاى تفريحسى و ... باشند (Perkins \& Long 2002).

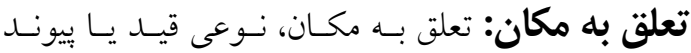

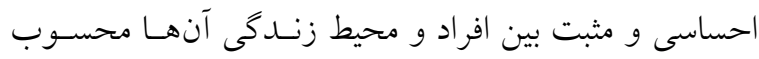

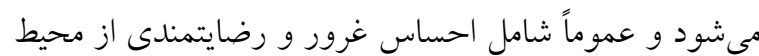

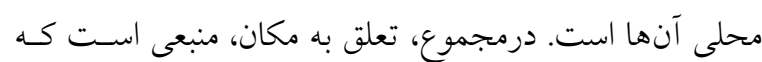

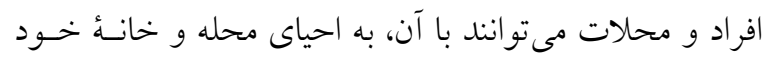

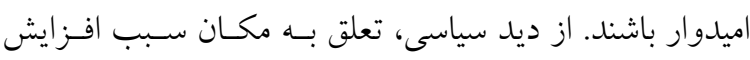

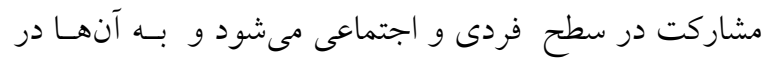

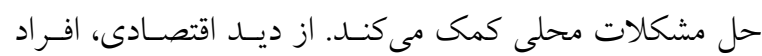

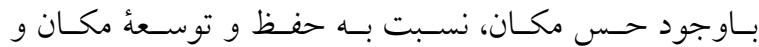
رخدادهاى محلى اقدام مى كند كه خود موجـــ فرصـتهـاى تجارى جديد است (Perkins \& Long 2002). رضايت از محله: اين مفهوم، نيز وابسته به مكان اسـت

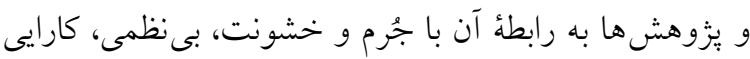
جمعى، انسجام محلى و ... اشارهكردهانـــ ( Perkins \& Long . (2002 محله كَرايـى ؛ ارزشى است در يــ محلـه كـه تـلاش

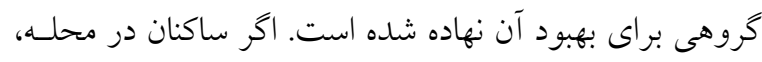
مشـاركت بيشـترى داشـته باشــند، جــو اجتمــاعى بــودن و 


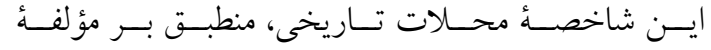
تو انمندسازى در مُدل سرمائُ اجتماعى است. به نظر مىرســ

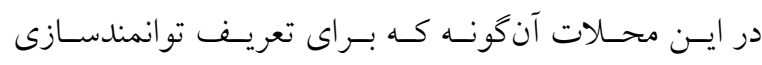

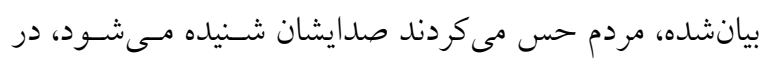

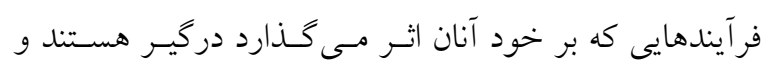

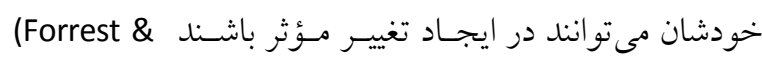

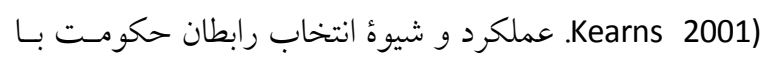
محله، مشاركت و حضور ساكنان در تصميم گيرىهاى محلى، .... همه، نشانهايى از مؤلفهُ توانمندسازى هستند. خودكفايى: در مركز محله، فضاهاى مذهبى، خدماتى و

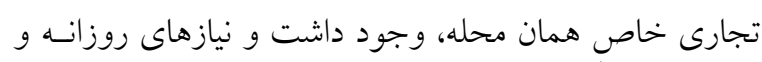

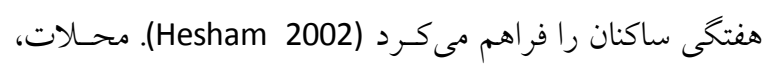

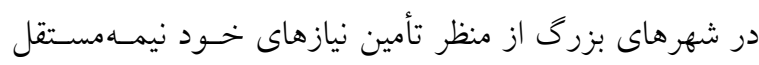
Sheikhy 2003; Tavasolli ) و بوداند (Ashraf 1975)

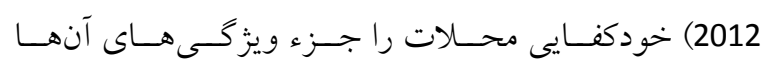
دانستهاند. باوجود خدماتى تجون حمام، مسجد، بازارجـهـ و ...

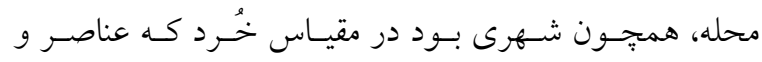

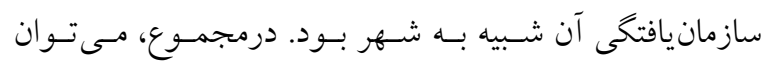

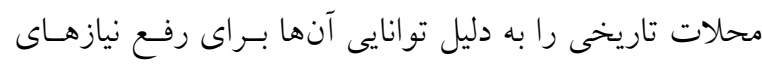

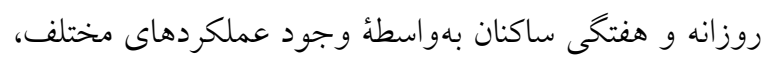

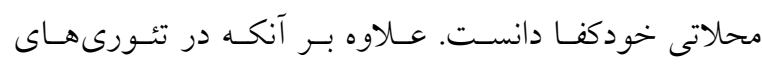

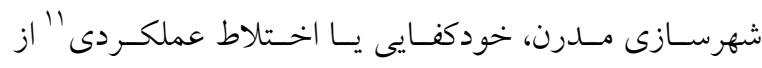
شاخصههاى محسلات محسـوب شــده اسـت (Talen 1999)، بثروهش ها به تأثير مستقيم آن بر سرمائُ اجتمـاعى ( Cabrera

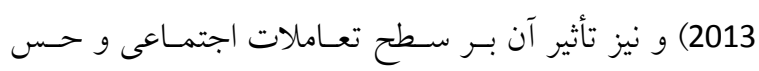
اجتمـاعى سـاكنان (Talen 1999 ; Francis et al, 2012) نيـز تئز اشارهكردهاند.

\section{ب. تر كيب اجتماعى}

محلات كه واحدهاى اصلى روابط اجتماعى در شهرها بودند، بيش از هر واحد ديخر شهرى همبستخى، يخانكى و همسـانى

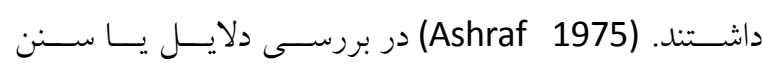
تقسيمبندى محلات در شهرهاى ايران، نمىتـوان بـه مبـاحثى

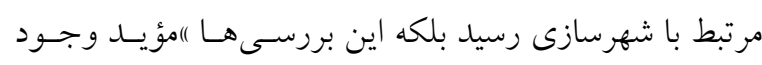

مانندِ كلانتر، كدخدا، محتسب، نقيب، عسس، داروغـه و ... در امورى جون قضاوت، اخــذ ماليـات، گسـترش محلـه، تـأمين امنيت و ... نقش داشتهاند. كلانتر، علاوه بـر تعيـين كدخــداو و وضع ماليات، در حل اختلافات كسبه، دفـاع از حقـوق رعايـا

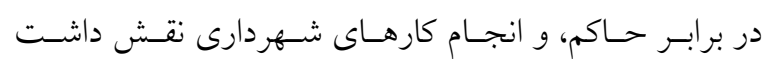

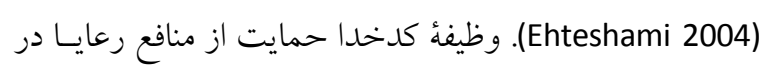

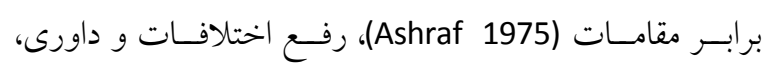

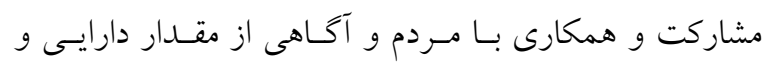
ويززخـى هــاى اجتمــاعى محلــه (Ehteshami 2004) بــود. محتسب، به كار كسترش و توسعة محلات و ساخت مسـكن

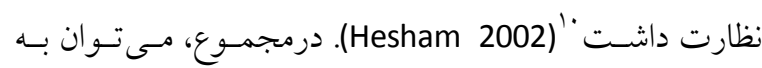

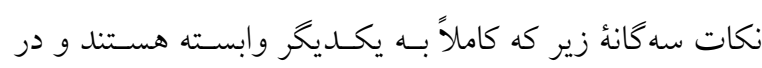

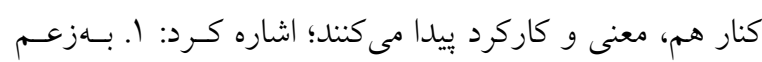
(Ehteshami 2004 ; Ashraf 1975 ; Hesham (كثـ منـابع) (Floor 1984 ; 2002 انتخاب اين افراد (كدخــدا، كلانتـر، ....) به طور مستقيم يا غيرمستقيم توسـط سـاكنان محلـه يـا شـهر

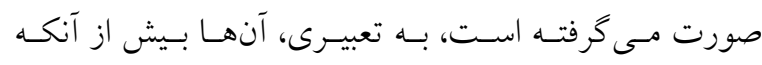

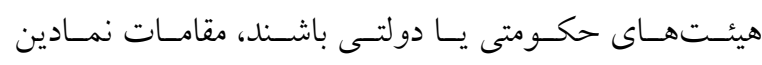

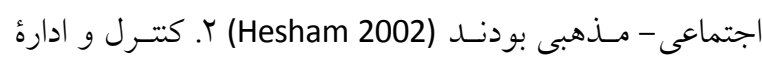

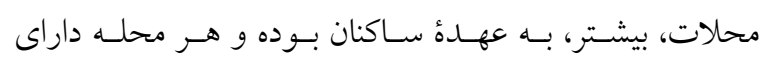

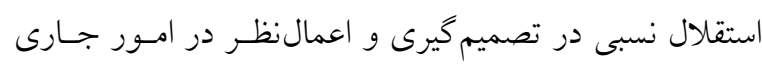

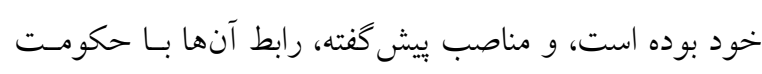

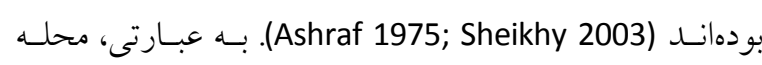

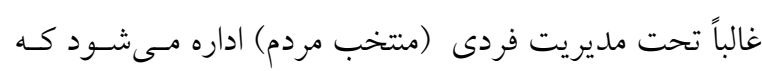

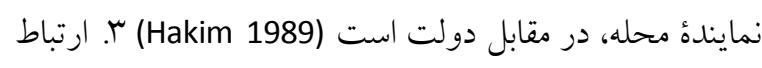

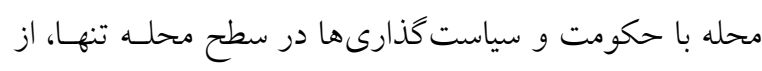
بالا به پايين و تحميلى نبوده و فرايندى از يايين به بالا نيز بــر

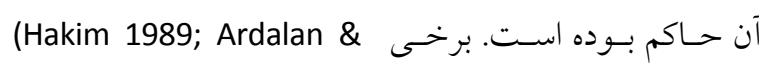

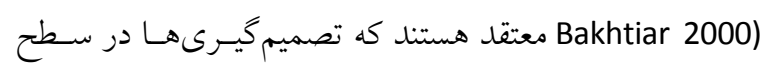
كلان و ساخت ابنئ عمومى، نظير مسجد جامع يا مدرسه، بـر

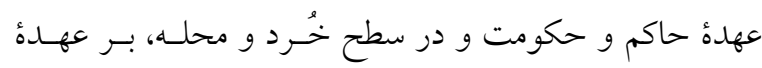

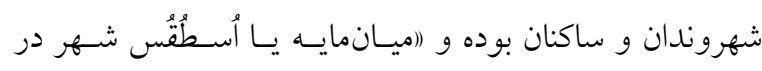
حيطة اختيار مردم باقى مى مانده است) (Ardalan \& Bakhtiar

. $(2000,126$ 
واكاوى ظرفيتهاى محيط كالبدى و اجتماعى محلات تاريخى در شكل گيرى سرمائٌ اجتماعى

جدول (: رابطه محيط اجتماعى محلات با سرمائُ اجتماعى

Table 1: Relation of social environment and social capital

\begin{tabular}{|c|c|c|c|c|}
\hline \multicolumn{2}{|c|}{ انطباق با مدل سرمائُ اجتماعى } & راهبرد اجتماعى & \multicolumn{2}{|c|}{ شاخصه اجتماعى } \\
\hline جزء شناختى & توانمندسازى & 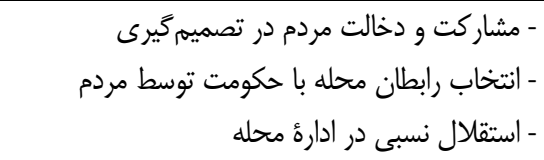 & كنترل و اداره & نظام \\
\hline جزء شناختى & حس اجتماعى & - استقلال محلى در عملكردها & خودكفايى & ادارى \\
\hline جزء شناختى & حس اجتماعى & 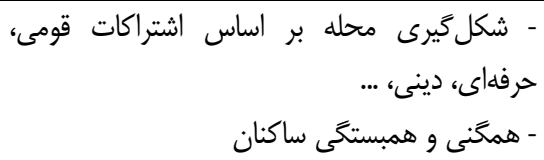 & اجتماعى & \\
\hline
\end{tabular}

رضايت از محله) و اجزاء رفتـارى (همسـايهدارى) نيـز اشـاره كرد (جدول (1).

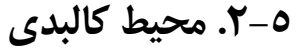

بررسى محيط كالبدى تحتِ سه عنوان صورت مى گيرد، الـف.

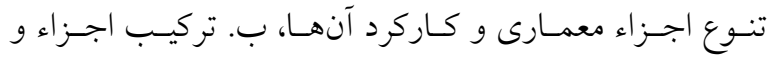
ساختار كلى، ج. معمارى اجزاء كالبدى و طراحى آنها.

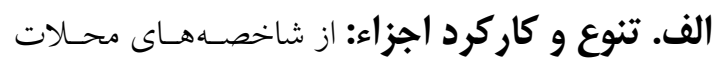

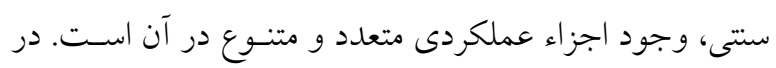

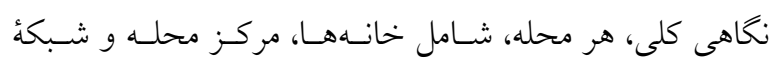

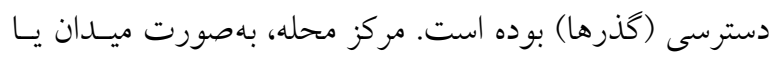

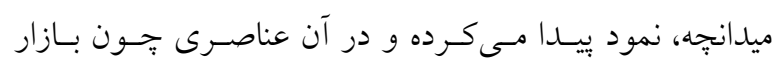

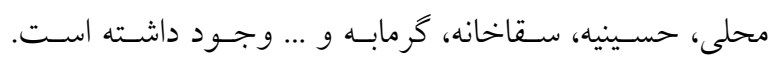

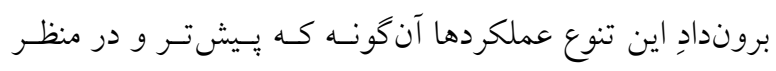

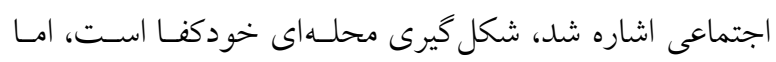

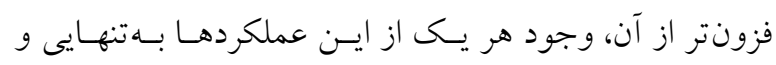

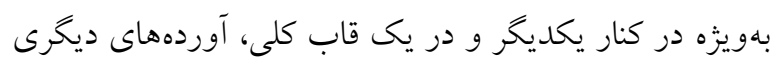

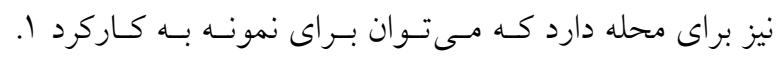
مسجد، ז. مركز محله و r. كذر اشاره كرد:

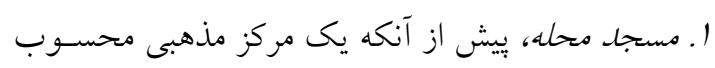

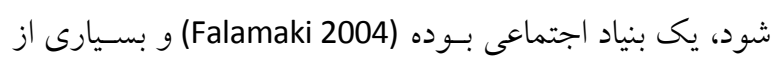

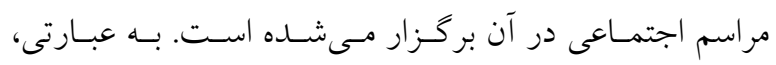

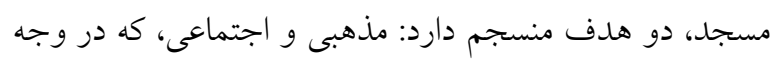

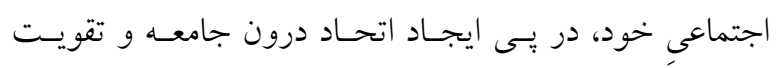

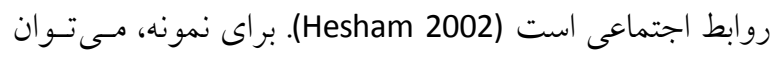

اصل تقسيمبندى شهر بر اساس واحدهاى اجتمـاعى متفـاوت) (Falamaki 2004, 168)

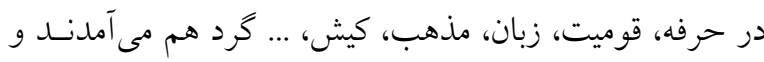

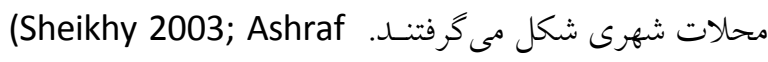
1975; Falamaki 2004) مؤلفههاى تأثير كذار بيان شده در مطالب بيشين، ميـان سـاكنان

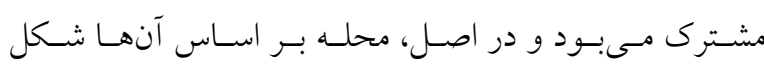

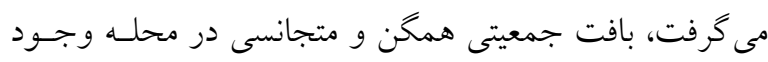

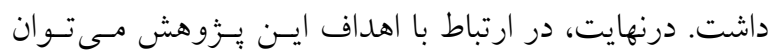

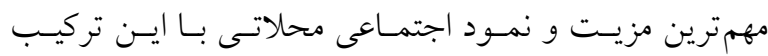

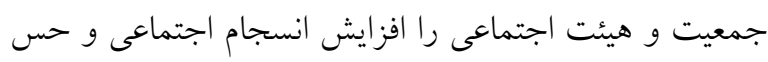

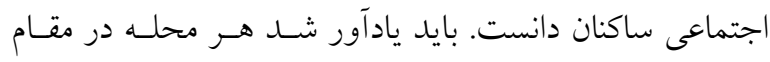
مقايسه با ديخر محلات، داراى تضادها و ناهمكنى هايى بود اما

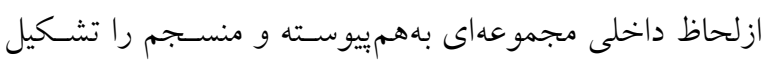

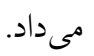
درمجموع، مى توان كفت ويزگى هاى برشـمرده از محيط

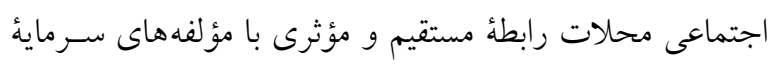

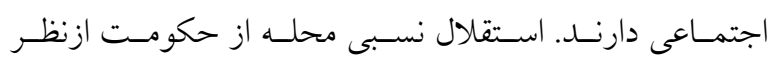

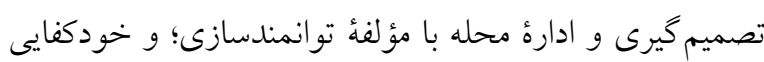

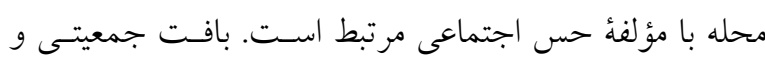

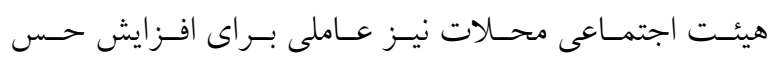

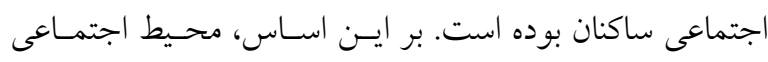

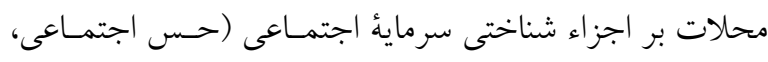

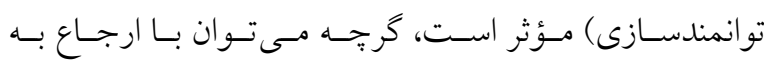

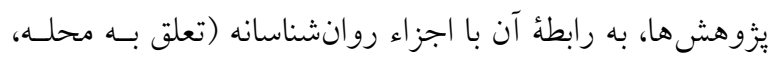

T.V | | 
فراوانى از آن، در كاشان، يزد و ... اشاره كرد.

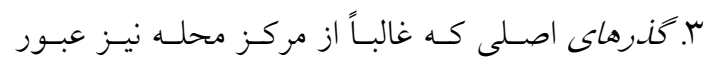

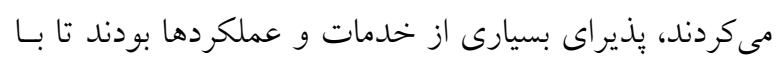

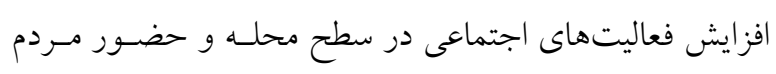

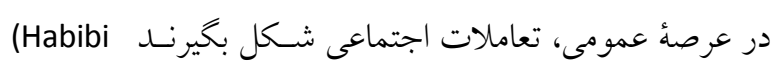

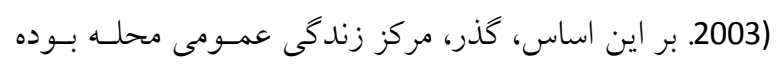

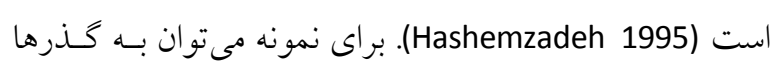

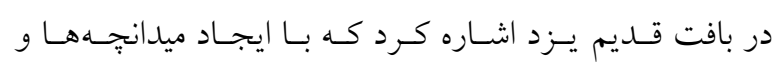

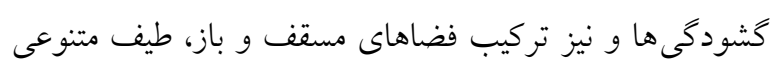

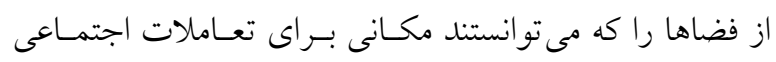

مختلف باشند؛ خلق كردهاند (تصوير بَ).

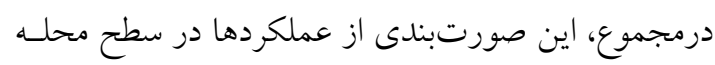

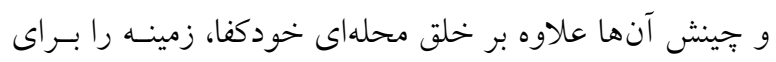
افزايش حضور ساكنان و كسترش تعـاملات اجتمـاعى فـراهم

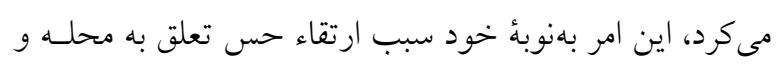
حس اجتماعى ساكنان مىشد.

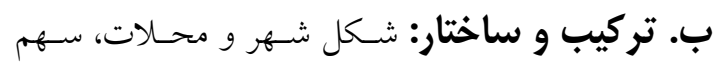

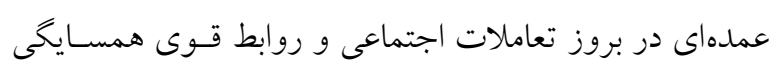

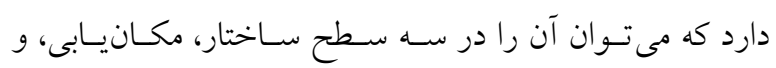
سازماندهى (سلسلهمراتـب) بررسى كـرد. از منظـر سـاختار،

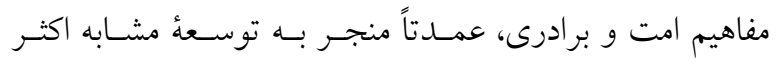

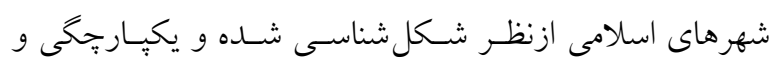

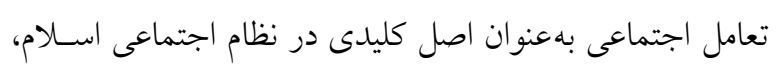

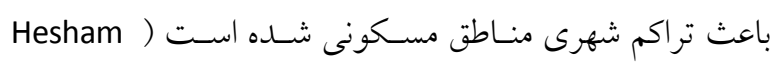

به حياط مساجد و حسينيهها اشاره كرد كه در بسـيارى مـوارد، على رغم وجود درهاى ورودىى، بخشى از فضاى عمومى شـهـ

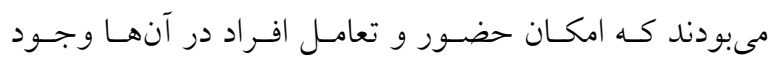

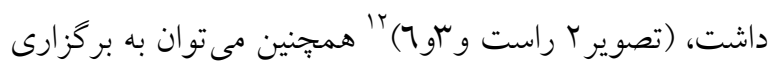

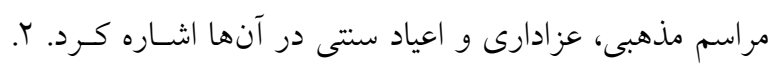

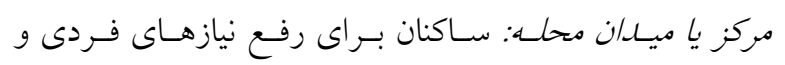

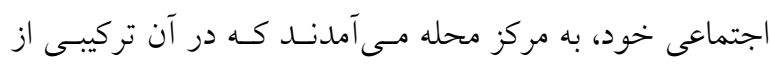

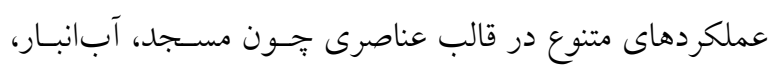

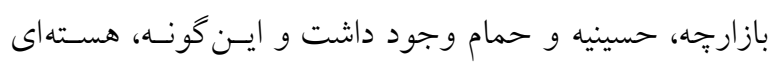

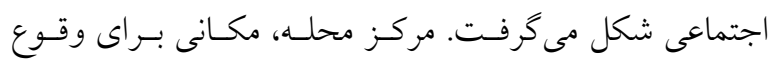

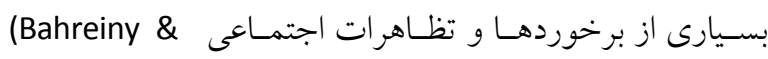
Tajbakhsh 1999)

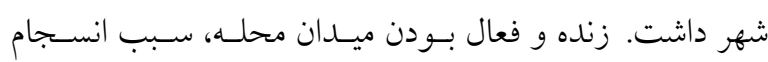

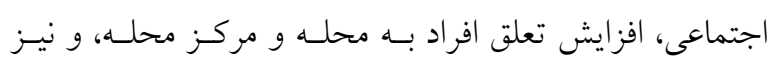

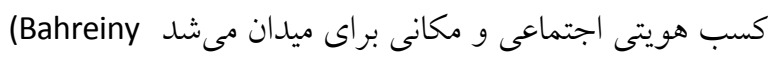

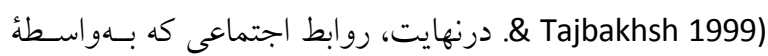

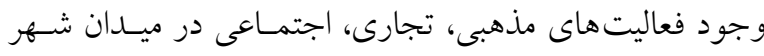

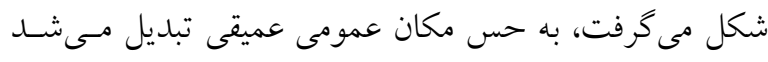
(Ardalan \& Bakhtiar 2000)

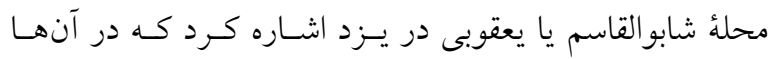
تركيب عناصـرى جـون مسـجل، مدرسـه، ... ديسـده مسى شـود

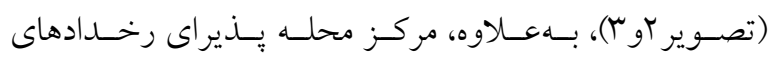

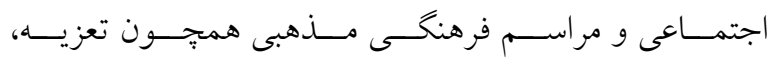

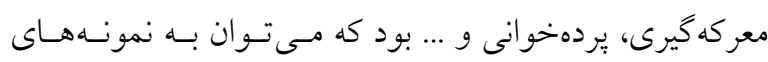
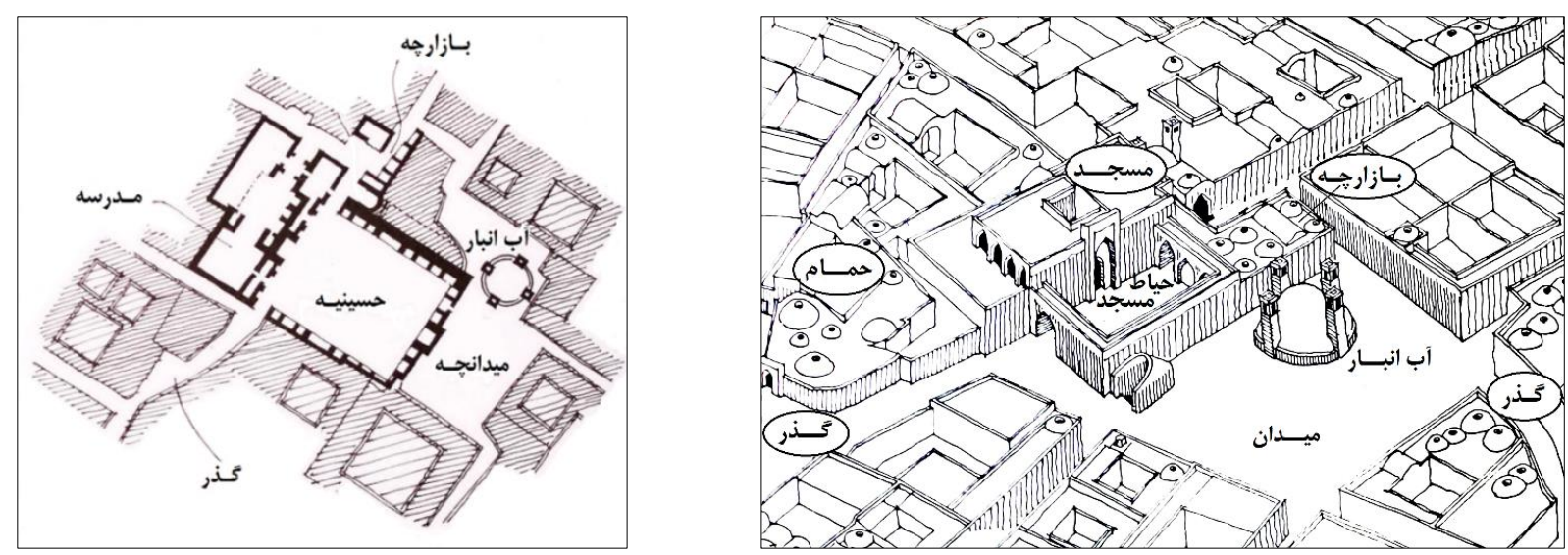

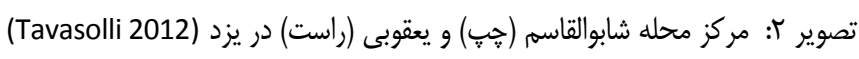

Fig. 2: Two community centers (in Yazd) (Tavasolli 2012) 


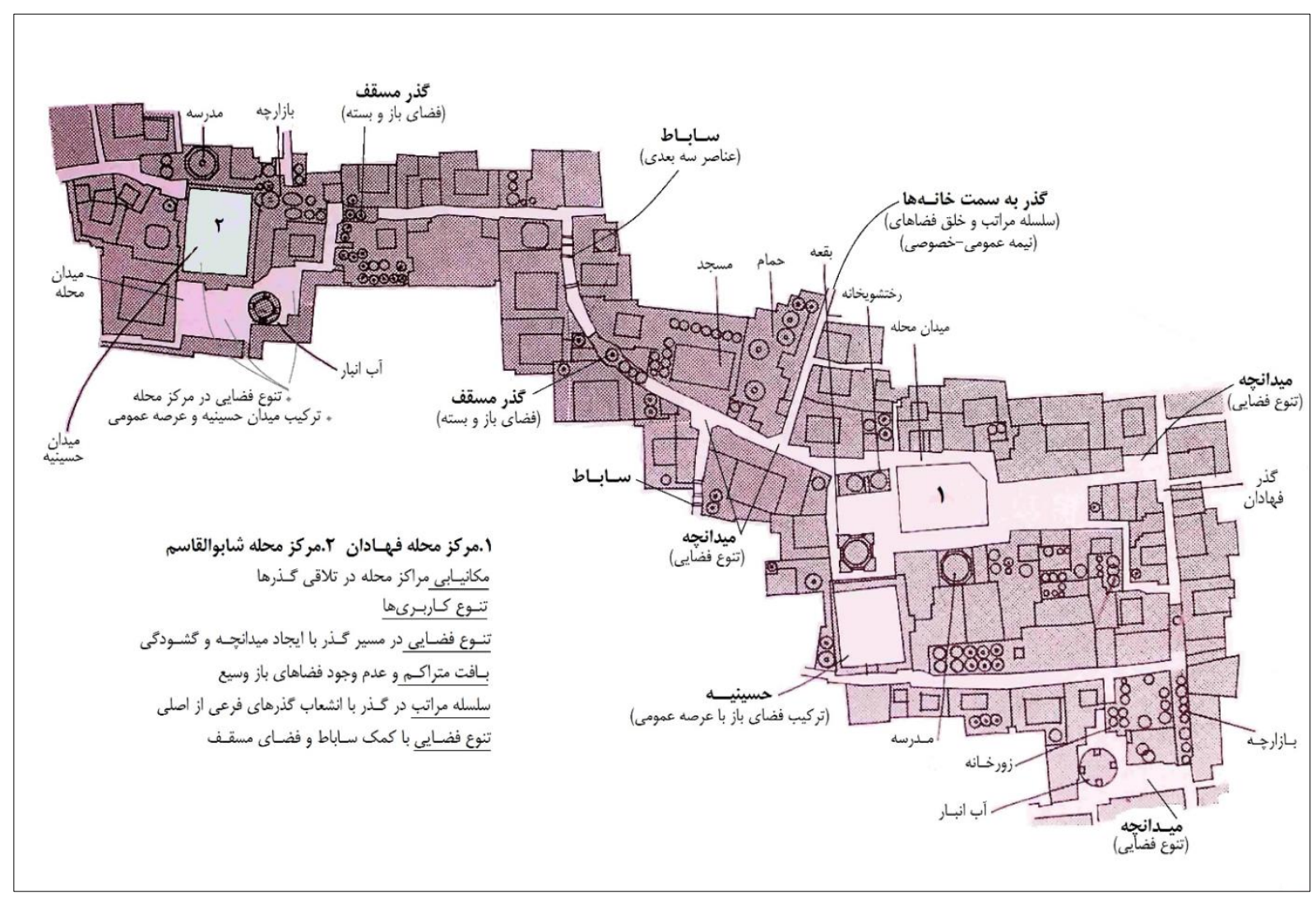

تصوير سّ: دو مركز محله در بافت تاريخى در يزد، تنوع عملكردى و فضايى، سلسلهمراتب كذرها و ... (Tavasolli 2012)

Fig. 3: Two community centers in Yazd, several functions and spatial variation (Tavasolli 2012)

(تصوير ץ). مشابه اين سازماندهى را مىتوان در گذرهاى بافت تاريخى سمنان و بيرجند نيز ديد. درمجموع، بافت

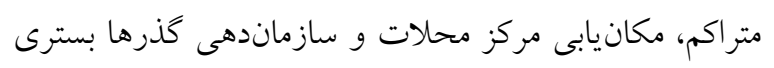

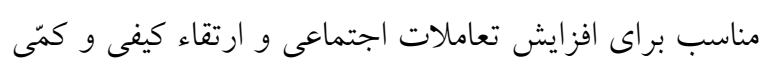

$$
\text { روابط بين همسايخان ايجاد مى كرد. }
$$

\section{ج. معمارى و طراحى: طراحى اجزاء و معمارى آنها}

كيفيتها و خصايصى را به كالبد محالات تاريخى بخشيدهانسا

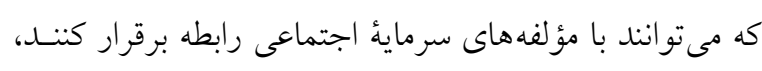
براى كشف اين رابطه، به كنكاش و دقت در طراحى معمارى

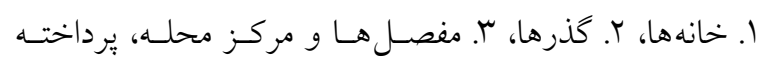

$$
\text { مىشود. }
$$

1. خانهها: ورودى خانه، حلقه ارتبـاطى درون و فضـاى

نيمهعمومى بيرون بوده است كه كيفيات طراحى و عناصـر آن ورودي

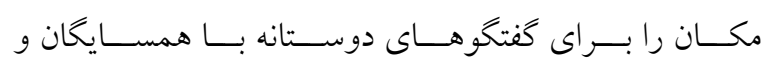

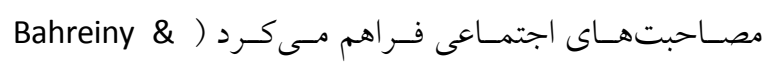
.(Naghizadeh. Zamani \& Karami 2010 ؛Tajbakhsh 1999 براى نمونه مىتوان به بيشبينى سكوهايى در ورودى خانهها
2002) و درنتيجه، شكل ظاهرى منطقه و كل شهر، از نوعى منطق فرهنكى، در جهت تحقق مفهوم ارتباط اجتماعى برخوردار است (Brown 1986). براى نمونه، مىتوان به عدم وجود فضاهاى باز و بزرى در محلات اشاره كرد كه از

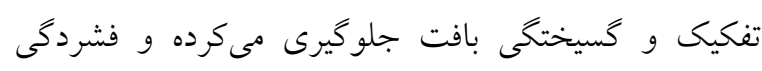

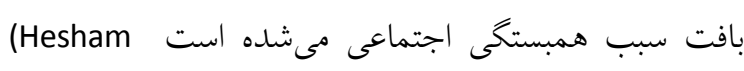

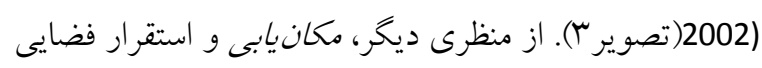
مراكز محلات در مسير يا تقاطع كذرهاى اصلى و نيز در مركز فيزيكى محله، امكان دسترسى آسان ساكنان و درنتيجه، حضور آنان را مهيا مىكرد. كذرها نيز بر اساس اصل محله محرميت و سلسلهمراتب، سازماندهى مىشدند بهنحوى كه قرارگيرى ورودى خانهها در كوجهایهاى بنبست، فضاهايى نيمه عمومى و مناسب را براى تعاملات همسايخان فراهم

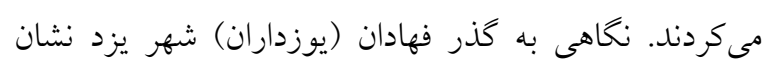

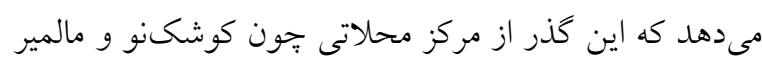

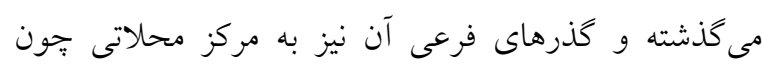
شابو القاسم، فهادان و درنهايت به خانهها دسترسى مىدادهاند

فرهنَ, معمارى و شهرسازى اسلامى - سال پنجم، شماره اول - بهار و تابستان 99 

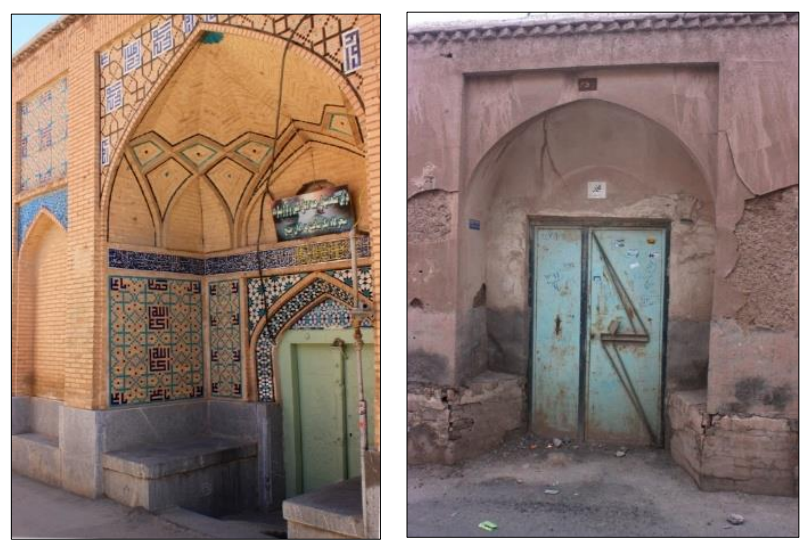

تصوير f: سكو، ييشطاق، قاببندى، و ... در ورودى خانه و يكى مسجد محلى در كرمان (عكس: حجت كلجين)

Fig. 5: Components of a house and local mosque entry in Kerman (Hojjat.Golchin)

(دستهاى از نمادها و علائم سلبعدى)" (Hesham 2002, 122)، به اين امر كمك مى كردند (تصويره). از سوى ديخر، (افضـاى

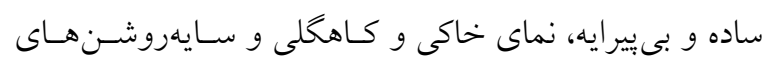

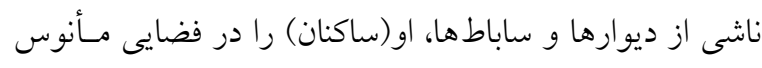

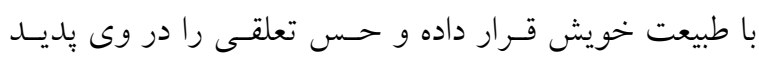

مى آورده) (Bahreiny \& Tajbakhsh 1999, 26)

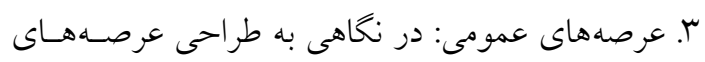

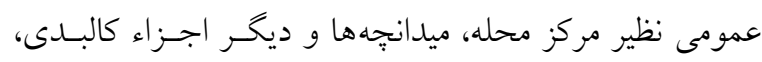

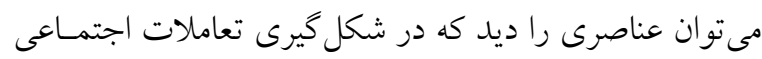
نقش مثبى دارند. (اتوجه ويزّه به نقاط تلاقى شهرى، همجيون دركاه خانهها، سر گذرها، ورودىى مساجد، مدارس، حمامهـا و .... موجب شكل گيرى شهرى با لولاهاى كالبـدى و اجتمـاعى

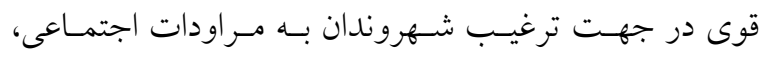

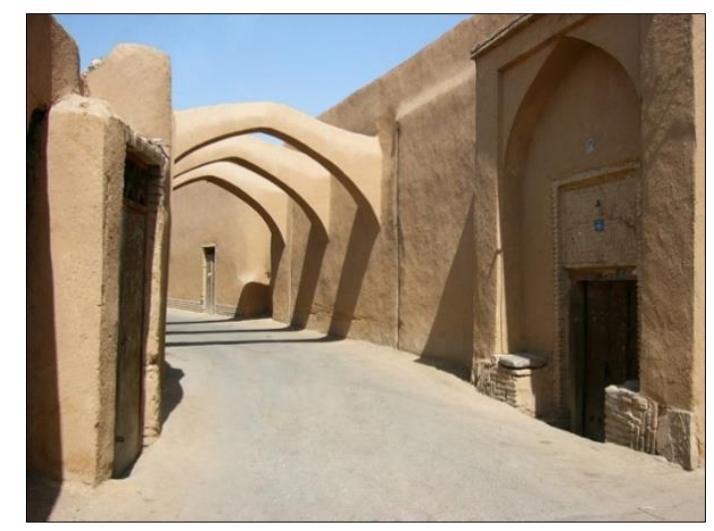

تصوير ه: يك كذر در يزد و تركيبى از عناصر سابعدى فضايى (www.irangardi.ir)

Fig. 5: Gozar in Yazd and a combination of spatial elements (www.irangardi.ir)
بـراى نشسـتن (ييرنشسين) اشـاره كـرد، بـهـعـلاوه برخـى از ورودى ها داراى بيش طاق (فضايى سريوشيده و نيمهباز مانند

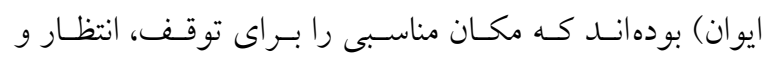
كفتخو فراهم مى كرده است (تصويرع). از سوى ديخر گرجـهـ در اين محلات، خانهها شبيه به هم بودهاند تا حسس تبعسي، تفاخر و اسراف در آنها نباشد، در همان حال تفاوتهايى در مقياس خُرد و در نماى خانه وجود دارد كه (انشانهاى رنح

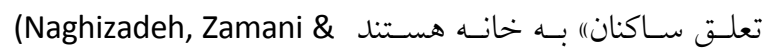
Karami 2010) اســتفاده از آجركـــارى، كاشـى كـــارى در رنخهاى متنوع و در قالب كتيبه يا لجّى و يـا قـاببنـدى در ورودى خانه، و به كاركيرى سـردر، در تركيبـات و ارتفاعـات مختلف از موارد قابل اشاره هستند (تصوير ع).

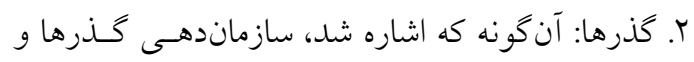
شكل گيرى سلسله مراتبى از عمومى به خصوصى، بـه حفـ اله

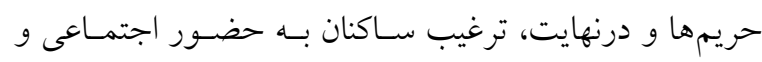
تعـاملات منجــر مسىشـد. يكـى از ابزارهــا بــراى بــروز ايسن

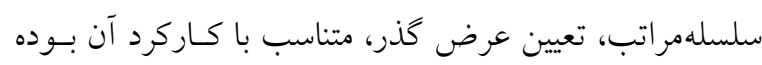

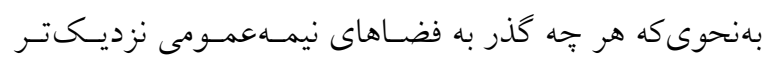
مى شده، عرض آن كاهش مى يافته است (تصوير r). گَـذرهاى كمعرض امكان تعامل رودررو را مقدور مى ساخته و مى تـوان كفت جنبههاى فيزيكى كو جههاى باريـى سـهم عمـدهاى در

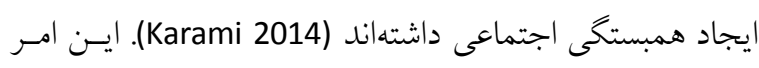
نه تنها با كاهش عرض، بلكـهـ بـا طراحسى آكاهانـه و صـحيح

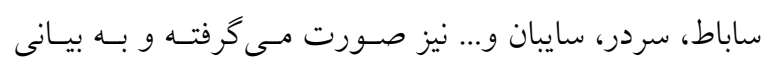




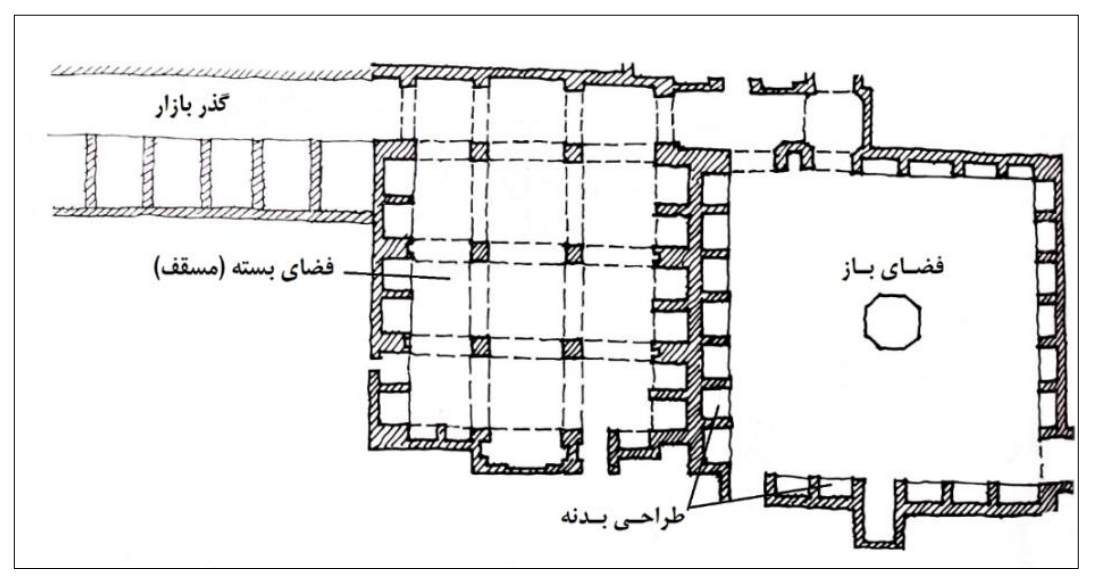

تصوير צ: تنوع فضايى (فضاى باز و بسته) در ميدان زواره (Madani Pour 2006, 62)

Fig. 6: Spatial variation - Open and enclosed spaces in Zavareh square (Madani Pour 2006, 62)

در جمع بندى سه شاخصـة كالبـدى محسلات، مسىتـوان

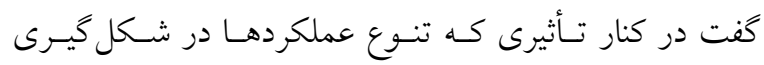

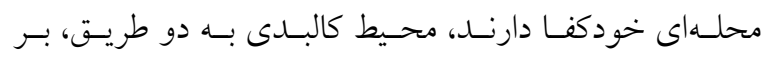

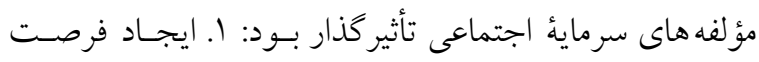

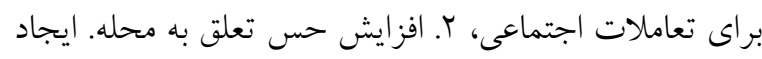

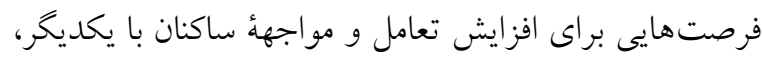
سبب مىشود حس اجتماعى و مؤلفهُ همسـايهدارى، در ميـان

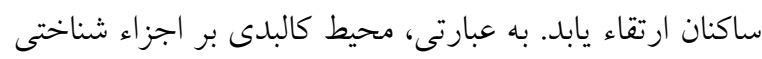

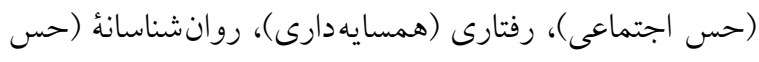

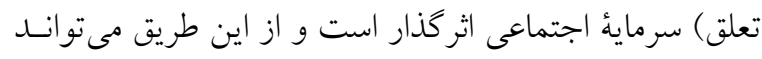

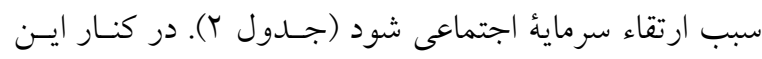

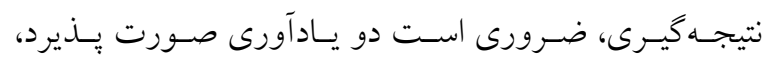

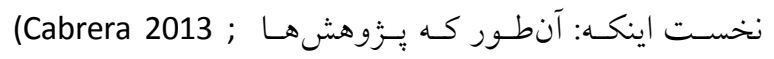
Soltanzadeh 2017)

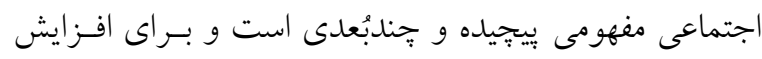

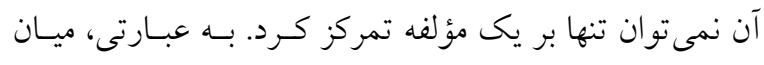

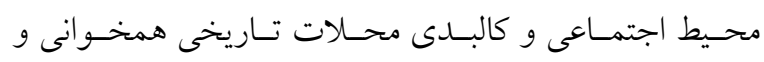

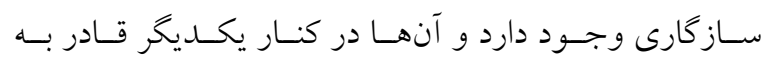

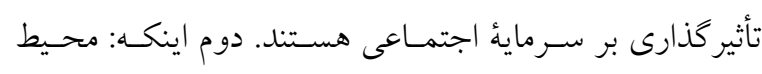

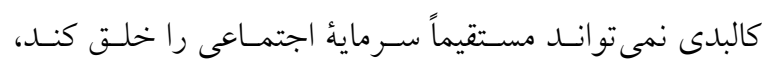
بنابر اين بيشنهادشـــ (Cabrera 2013; Holtan et al, 2014) كه تمركز محققان بر مكانيسمهايى نظير ايجـاد فرصتهايى براى تعامل يا افزايش حس تعلق باشد كه بهطور

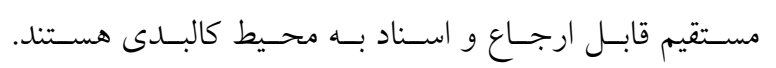

مهماننوازى ... مسىشـده اسـت) (Madani Pour 2006, 62).

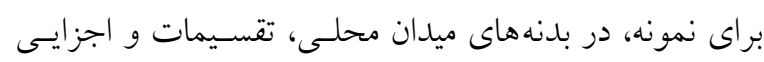

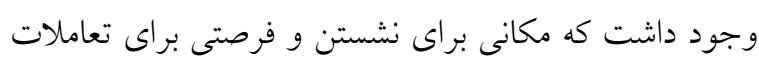

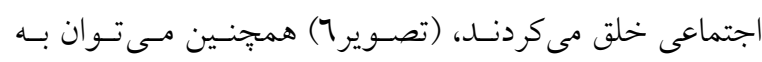
جلوخان يا ييش طاق در ورودى برخى بناهاى عمـومى اشـاره

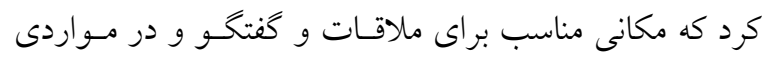

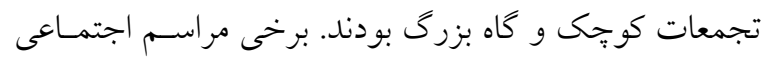

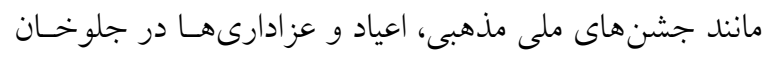

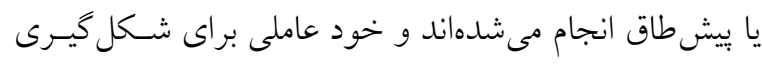
الكوهـاى رفتـارى سـاكنان بـودهانـــ (Soltanzadeh 2005).

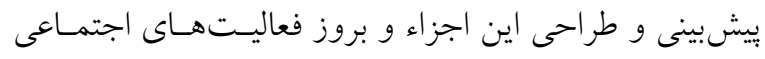

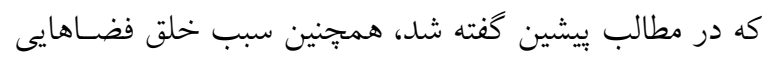

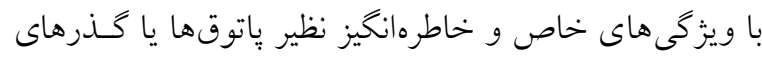

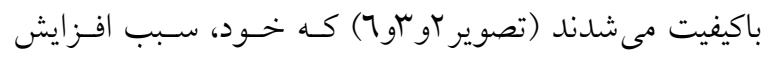

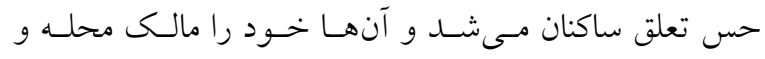

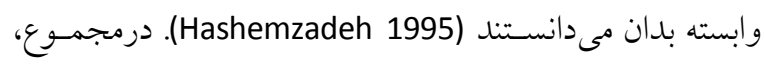
مى توان گفت در طراحى هر يكى از عناصر كالبدى محله نظير

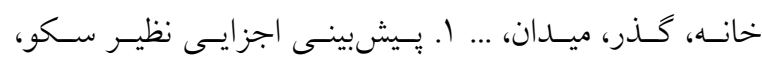

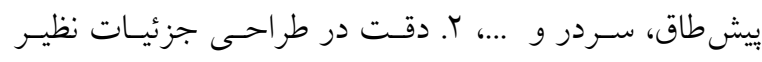

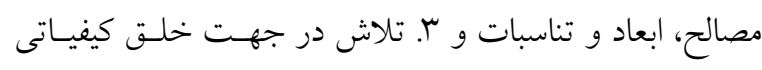

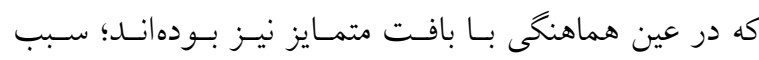

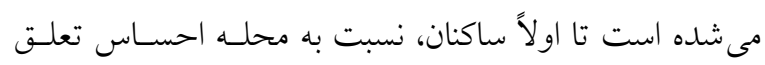

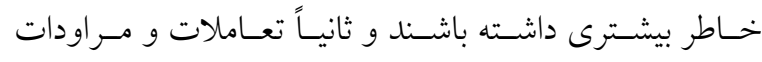
اجتماعى بين ساكنان و همسايگان افزايش يابد. 
جدول ז: رابطه محيط كالبدى محلات با سرمائٌ اجتماعى

Table 2: Relation of built environment and social capital

\begin{tabular}{|c|c|c|c|c|c|}
\hline \multicolumn{2}{|c|}{ انطباق با مدل سرمائُ اجتماعى } & \multicolumn{2}{|l|}{ راهبرد كالبدى } & آوردة اجتماعى & شاخصه كالبدى \\
\hline جزء شناختى & خودكفايى & تنوع عملكردها & مركز محله & \multirow{3}{*}{ خ تعامل اجتماعى اجتماعى } & \multirow{3}{*}{ تنوع و كاركرد } \\
\hline جزء شناختى & حس اجتماعى & 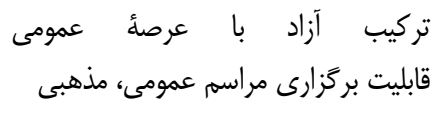 & 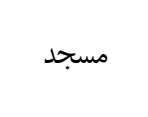 & & \\
\hline جزء روانشناسانه & ت تعلق به مكان & 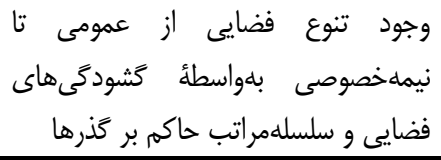 & كذر & & \\
\hline جزء شناختى & حس اجتماعى & 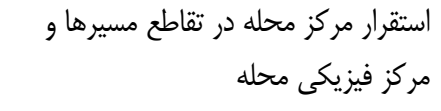 & مركز محله & \multirow{3}{*}{ همسايگان } & \multirow{3}{*}{ ت تر كيب و ساختار } \\
\hline \multirow{2}{*}{ جزء رفتارى } & \multirow{2}{*}{ 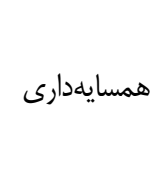 } & تراكم و عدم وجود فضاهاى باز وسيع & 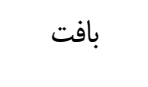 & & \\
\hline & & سلسلهمراتب و حريم دركذرها & كذر & & \\
\hline جزء شناختى & حس اجتماعى & 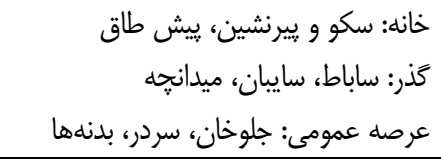 & معنش عيشى & \multirow{3}{*}{ حس تعلق اجتماعى } & \multirow{3}{*}{ معمارى و طراحى } \\
\hline جزء رفتارى & همسايهدارى & خذانه: كاشيكارى، آجر كارى، قاببندى كمى نماى ساده و بى بييرايه & مصالح، ابعاد، & & \\
\hline جزء روانشناسانه & تعلق به مكان & تاتوق در ورودىها و سردرها، شكل گيرى & تنوع كيفى & & \\
\hline
\end{tabular}

\section{نتيجه كَيرى}

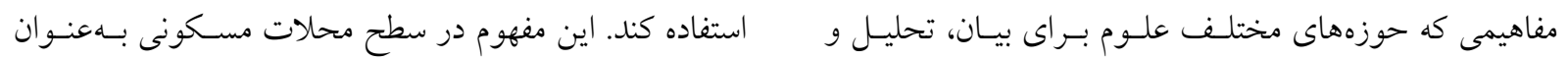

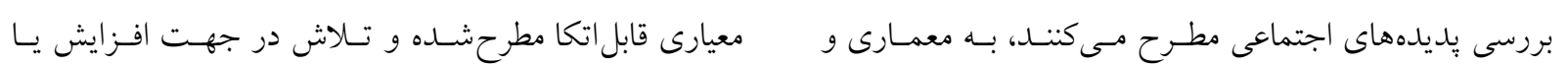

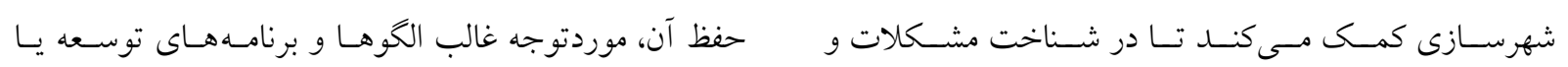

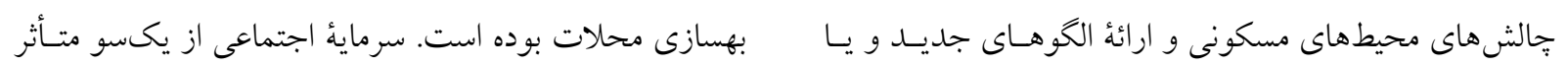

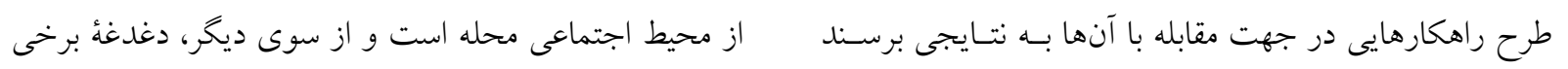

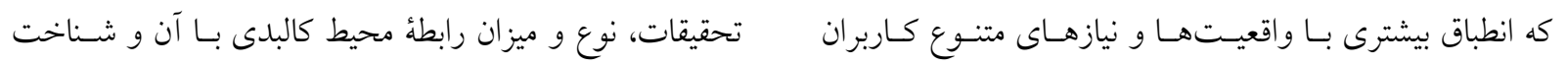

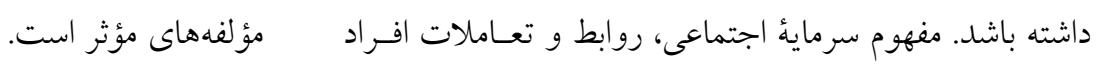

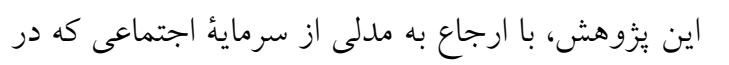

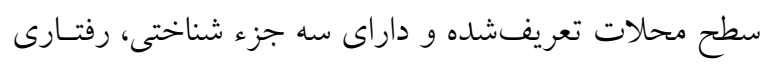

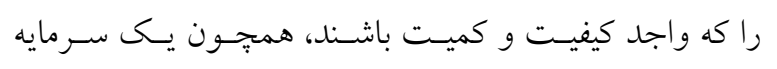

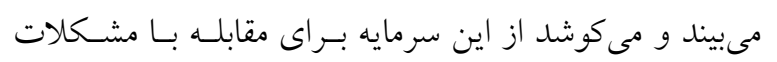


واكاوى ظرفيتهاى محيط كالبدى و اجتماعى محلات تاريخى در شكلگيرى سرمائً اجتماعى

براى حضور فعال سـاكنان در سـطح محلـه، فـراهم كنــد. بـهـ عبـارتى يسيشبينسى صسحيح از نيازهـاى اجتمـاعى سـاكنان و

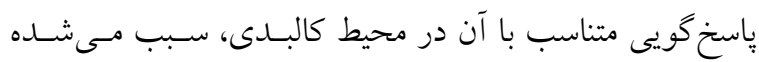

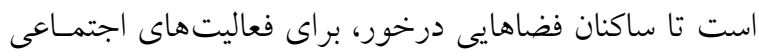
خود در سطح محله داشته باشند، در آن حضور يابند و سـطح تعاملات اجتماعى افزايش يابد. طراحسى عناصـر كالبـدى، بـا دقت در بيشبينى يا تعبية اجزاء (سردر، سايبان، ...)، انتخـاب مصالح، و خلق كيفيات فضايى (بسته و بـاز بـودن، تناسـبات،

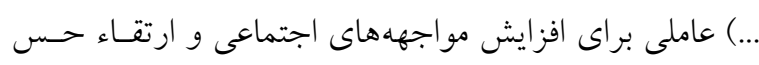

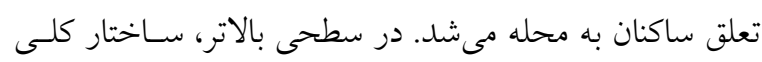

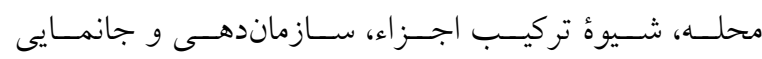
عملكردهايى جهون خانـه، كـذر و ميـدان در جهــت افـزايش تعاملات اجتماعى بوده است. بر اين اسـاس، محسيط كالبـدى محلات مشخصاً با تلاش در جهت ا. افزايش ميزان تعاملات

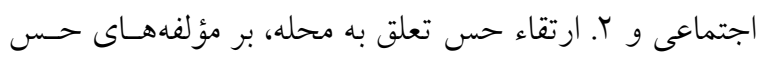

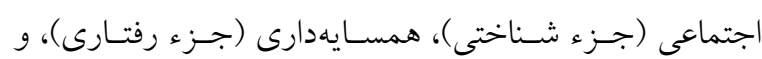

حس تعلق (جزء روانشناسانه) تأثير كذار است (تصويرV). اين نتايج، مؤلفها و جهت گيرى هايى را نشان مسىدهنــ

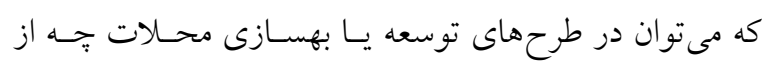
منظر طراحى معمارى و شهرسازى و جّه از منظر شـكلدهى و سياسـت كـذارىهـاى اجتمــاعى، بـــانهـا توجـهـ كـرد. در كاربست اين نتايج و نظر به بيتيجيدگى مفاهيم حوزهُ مسـكن و مفهوم سرمائُ اجتماعى، ضسرورى اسـت يـادآورى شـود اولاً شاخصهاى ذكرشده براى محيط كالبدى در كنـار يكـديخر و

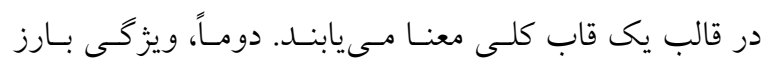

و روانشناسـانه اسـت، بـهـ بررسـى رابطــهُ محـيط كالبـدى و

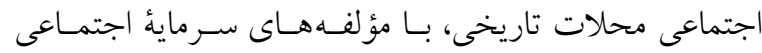
مىيردازد. شاخص هاى محيط اجتماعى، (انظـام ادارى (كتــرل و اداره، خودكفايى)") و (تركيـب اجتمـاعى") و شـاخص هـاى محسيط كالبـدى، ((تنـوع و كـاركرد))، (اتركيـب و سـاختار)) و (معمارى و طراحى)، معرفى شدند. اين يزوهش، ضمن اذعان

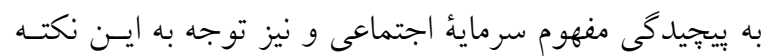

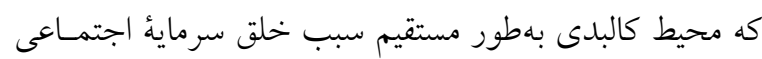

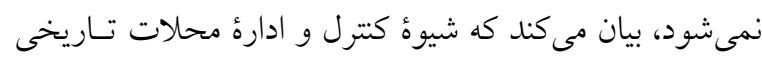
منطبق با مؤلفه توانمندسازى در مدل سرمائُ اجتماعى اسـت. از سوى ديخر خودكفايى محلات و نيز تركيب اجتماعى آنها

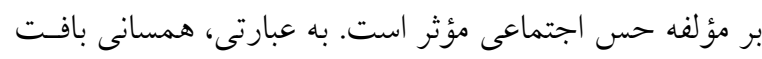

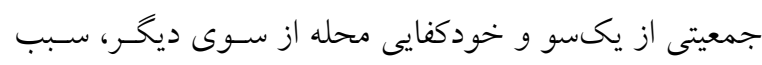
افزايش تعاملات اجتماعى مىشود. همراه با افزايش تعـاملات

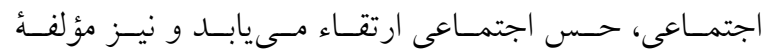
همسايهدارى ميان ساكنان قوىتر مسىشـود. بـهـ بيـانى مـوجز،

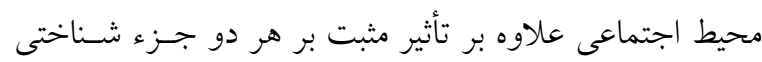
سرمائُ اجتماعى (تو انمندسازى، حس اجتماعى) مى توانــ بــر اجزاء رفتارى سرماية اجتمـاعى (همسـايهدارى) نيـز اثركـذار باشد. از سوى ديخر، اجزاء محيط كالبدى محلات داراى تنوع بودهاند و كاركردهاى مختلفى داشتهاند. تنوع كاركردها سـبب مىشد كه محلهاى خودكفا ازنظر تأمين نيازهاى ساكنان شكل

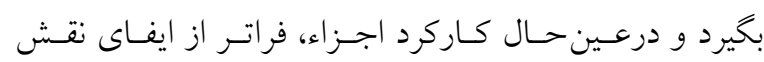
عملكردى صرف باشد، بلكه بعضاً (مسـجد و ميـدان محلـه) نقشى اجتماعى را نيز بر عهلده داشته باشد و بسـتر مناسـب را

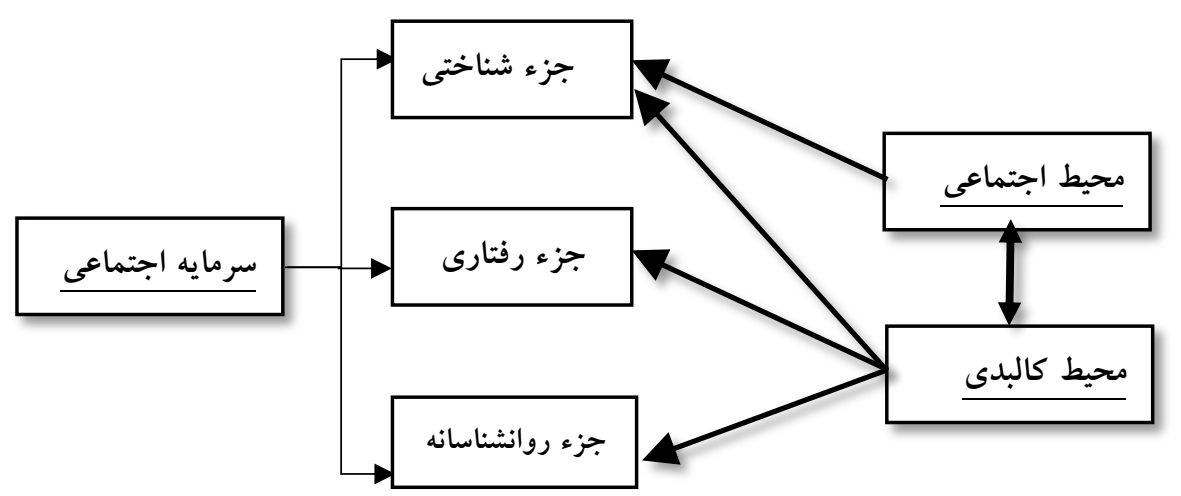

تصوير V: رابطةٔ محيط كالبدى و اجتماعى محلات با سرمائُ اجتماعى

Fig. 7: Relation of social and built environment and social capital 
خلق كيفيات فضايى، مكانيـابى مناسـب و ...، بــون وجـود محيط اجتماعى مطلوب، اعم از بافت جمعيتـى، شـيوه اداره، سطح استقلال و ...، محلهاى با سطح سرمائُ اجتماعى بالا بـه دست نمى دهد و بالعكس.
محلات تاريخى، سـاز كارى، انطبـاق، همخــوانى و همسـويى محيط كالبدى و اجتماعى اسـت و بسـيارى از شاخصسههـا و كيفيات ممتاز آنها بدون اين ويزگى حاصل نمسىشـود. تنهـا،

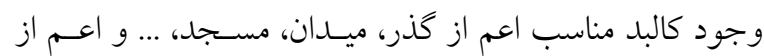

\section{يقيىنوشتها}

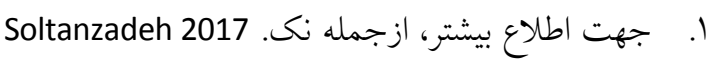
Asset Based Community Development(ABCD) . . Sense of Community r Empowerment .2 0. مeادلهاى ديخرى جهون "روابط همسايكى" نيز براى اين وازه بيشنهادشده است.

Citizen participation .7

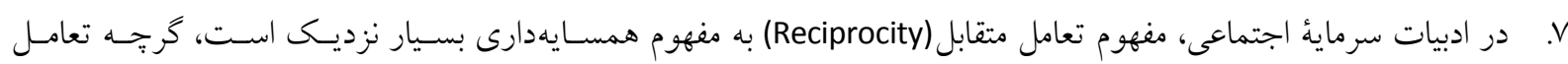
متقابل صرفاً در همسايخى معنى نمى يابد.

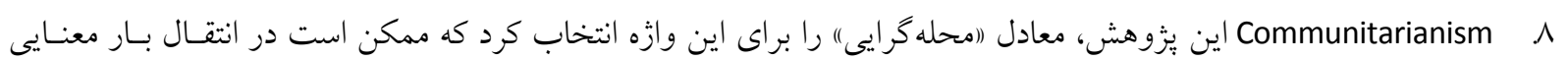
وازه با نواقصى نيز روبرو باشد.

9. محلات در شهرهاى اسلامى حضور داشتهاند و برخى آراء كه در متن آمده خطاب به آنها و نه صرفاً ايران است. •. . جهـت اطلاع بيشتر از وظايف هر يك از مناصب مذكور ازجمله نكى : (Ehteshami 2004; Floor 1984) Land Use Mixed .11 r ا. كلئ عكسها بر اساس اهداف يزوهش، ويرايش شدهاند.

\section{فهرست منابع}

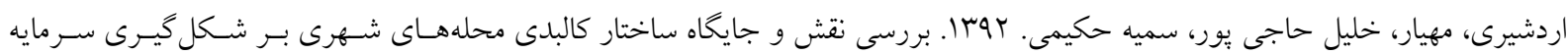

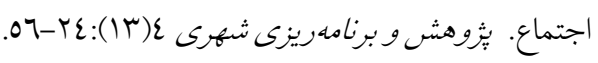

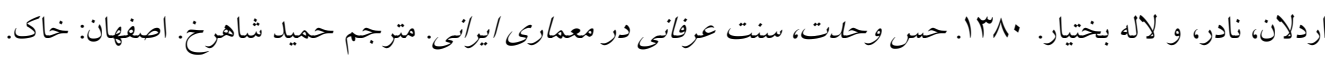
احتشامى، لطفاله. عیما. نقش كلانتران و كدخدايان در ملديريت شهر و روستا. اصفهان: مهرقائم.

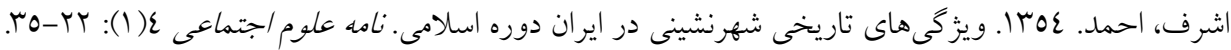

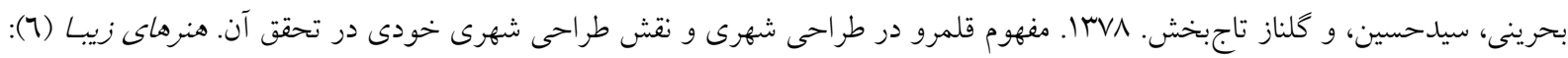
.

$$
\text { باكزاد، جهانشاه. }
$$

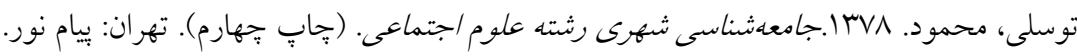
توسلى، محمود. الوبا.ساخت شهر در /قليم كرم و خشكى /يران. تهران: ييام.

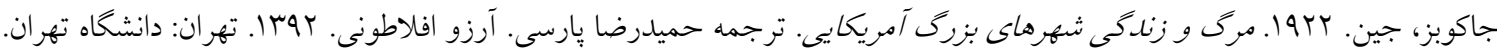

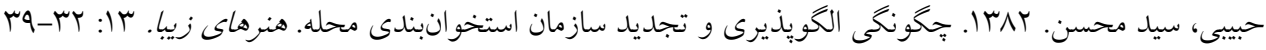

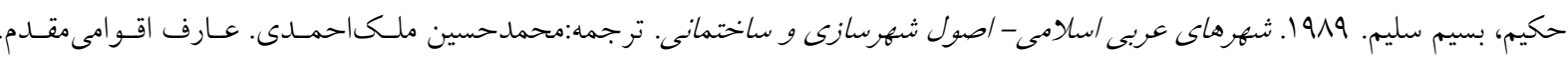

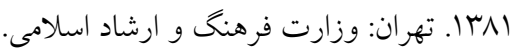

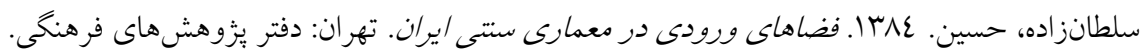

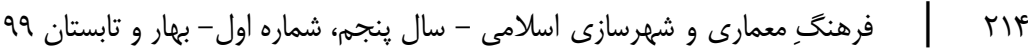


واكاوى ظرفيتهاى محيط كالبدى و اجتماعى محلات تاريخى در شكلگيرى سرمائً اجتماعى

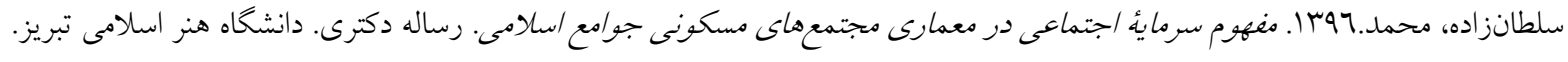

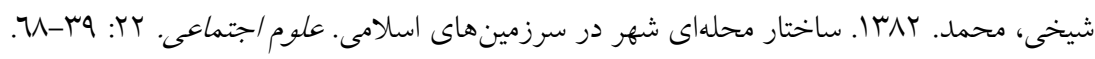

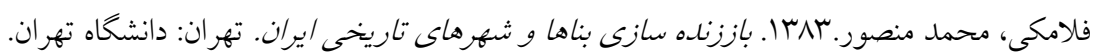

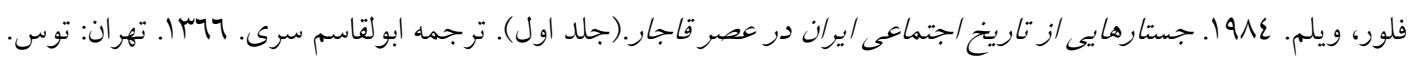

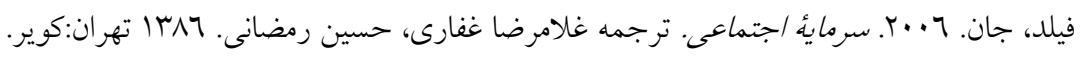

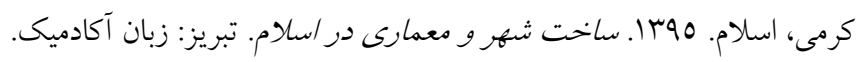

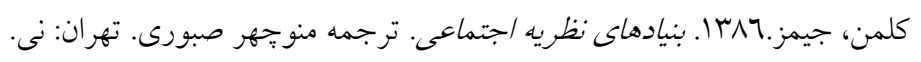

$$
\begin{aligned}
& \text { مدنى يور، على. }
\end{aligned}
$$

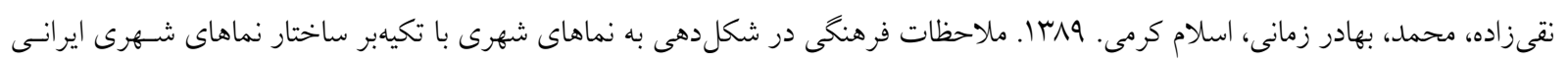

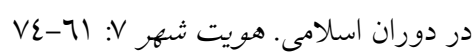

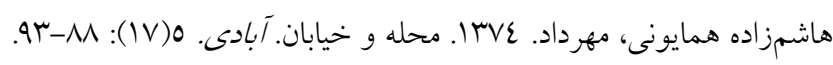

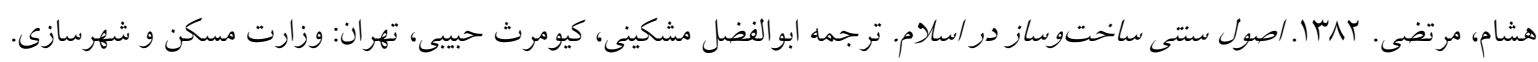

\section{منابع انكَليسى}

Ardalan, N., \& L. Bahktiar. 2000. The Sense of Unity: The Sufi Tradition in Persian Architecture. Translated by Shahrokh, H. Esfahan: khak. [In Persian]

Ardeshiri, M., Kh. Hajipoor, \& Hakimi, S. 2013. Role of physical infrastructure in urban neighborhoods on the formation of social Capital. Research and Urban Planning 4(13):24-56. [In Persian]

Ashraf, A. 1975. Historical Characteristics of Urbanization in the Islamic Period, Journal of social science letter. 4(1):22-35. [In Persian]

Bahreiny, S. H., \& G. Tajbakhsh. 1999. The concept of Territory in Urban Design and The Role of Urban Design Itself in its Realization. Honarhay-e-Ziba (6): 18-31. [In Persian]

Brown, K. 1986. The Use of a Concept: The Islamic City. in Middle Eastern Cities in Comparative Perspective.

Ed. K, Brown. 107-129. London: Ithaca Press

Bourdieu, P. 1985. The forms of capital. In Handbook of Theory and Research for the Sociology of Education, ed. J.G. Richardson, 241-258, New York: Greenwood.

Cabrera, J.F. 2013. New Urbanism and Selection Bias in the Formation of Social Capital. Housing Policy Debate 3(2): 376-394.

Coleman, J. 2006. Foundations of Social Theory. Translated by Manouchehr Saboori. 2007. Tehran, Nei. [In Persian]

Ehteshami, L. 2004. The Role of kalantar and kadkhoda in city and village management. Esfahan: Mehr-e-ghaem. [In Persian]

Falamaki, M.M. 2004. Regeneration of Iranian Historical Buildings and Cities. Tehran: Tehran University. [In Persian]

Field, J. 2006. Social Capital. Translated by Gholamreza Ghaffari, Hosein Ramazani. Tehran: Kavir. [In Persian]

Floor, Willem. 1984. Studying of Social History of Iran in Qajar Period. Vol: 1. Translated by Abolghasem Serri. 1987. Tehran: Toos. [In Persian]

Forrest, R., A. Kearns. 2001. Social Cohesion, Social Capital and the Neighbourhood. Urban Studies. 38(12): 2125-2143.

Francis, J., B. Corti, L. Wood, A. Knuiman. 2012. Creating sense of community: The role of public space. Journal of Environmental Psychology 32: 401-409.

Jacobs, J. 1992. The Death and Life of Great American Cities, Translated by Hamidreza Parsi and Arezoo Aflatooni.2013. Tehran: Tehran University. [In Persian]

Habibi. H. 2003. How to follow the examples and reorganize the community frame work. honar hay-e ziba 13:32-39. [In Persian]

Hakim, B. S. 1989. Arabic-Islamic Cities. Building and Planning Principles. Translated by Mohammad. A, M.Ahmadi. \& Aref, Aghvami. 2002. Tehran: Ministry of Culture and Islamic Guidance. [In Persian]

Hesham, M. 2002. Traditional Islamic Principles of Built Environment. Translated by Abolfazl, Meshkini. And Kioumars, Habibi. 2008. Tehran: Road, Housing \& Urban Development Research Center. [In Persian]

Hashemzadeh, H. 1995 Community and Street. Abadi 5(17): 61-74. [In Persian]

Holtan, M. T., S. L. Dieterlen, W. C. Sullivan. 2014. Social life under cover: Tree Canopy and Social Capital in Baltimore, Maryland. Environment \& Behavior 46(6): 1-24

Karami, E. 2016. Social principle of City Construction and Architecture in Islam. Tabriz: zaban academic. [In Persian]

Mihaylov, N. \& D.D. Perkins. 2013. Community Place Attachment and its Role in Social Capital Development in Response to Environmental Disruption. In Place Attachment: Advances in Theory, Methods and Research, ed. L. Manzo. \& P. DevineWright. London: Routledge.

Madani Pour, A. 2006. Is Attention to City Appearance Important? Abadi 53:62-65. [In Persian]

Naghizadeh, M., B. Zamani, \& I. Karami. 2010. Cultural Consideration in Urban Facade Formation: Emphasize on urban facade 
formation in Iranian Islamic architecture. Hoviatshahr 7:61-74. [In Persian]

Pakzad, J. 1990. Neighbourhood. Soffeh. 1(1):16-20. [In Persian]

Perkins, D.D., \& D.A. Long. 2002. Neighborhood Sense of Community and Social Capital: A Multi-level Analysis. In Psychological Sense of Community: Research, applications, and implications. ed. A. Fisher, C. Sonn, and B. Bishop, 291-318. New York: Plenum

Putnam, R. D. 1996. Who Killed Civic American? Prospect 7(24): 66-72.

Scottish Executive. 2002. Closing the Gap: The Scottish Executive's Community Regeneration Statement.

Sheikhy, M. 2003. Neighborhood Structure of the Past Islamic Cities. Social Science. 22:39-68. [In Persian]

Skjaeveland, O., T. Garling, \& J. G. Maeland. 1996. A Multidimensional Measure of Neighboring. American Journal of Community Psychology 24: 413-435.

Soltanzadeh, H. 2005. Entry Spaces in the Traditional Architecture of Iran. Tehran: Cultural Studies [In Persian]

Soltanzadeh, M. 2017. The Concept of Social Capital in Residential Complex in Islamic Societies. PhD diss., Islamic Art University. [In Persian]

Talen, E. 1999. Sense of community and neighbourhood form: An assessment of the social doctrine of new

urbanism. Urban Studies 36(8): 1361-1379.

Talen, E. 2000. Measuring the public realm: A preliminary assessment of the link between public space and sense of community. Journal of Architectural and Planning Research. 17: 344-360

Tavasolli, M. 1999. Urban sociology, Tehran: Payam Noor. [In Persian]

Tavasolli, Mahmud. 2012. Urban Structure and Architecture in the Hot Arid Zone in Iran, Tehran: Payam. [In Persian]

Unger, D. G., \& A. Wandersman. 1985. The Importance of neighbord: The Social, Cognitive, and Affective Components of Neighboring. American Journal of Community Psychology 13:136169

Wissink, B., A. Hazelzet. 2012. Social Networks in 'Neighbourhood Tokyo. Urban Studies 49(7): 1527-1548. 